\title{
Do Servant Leadership Self-Efficacy and Benevolence Values Predict Employee Performance within the Banking Industry in the Post-COVID-19 Era: Using a Serial Mediation Approach
}

\author{
Tasmeer Mujeeb ${ }^{1}$, Noor Ullah Khan ${ }^{1,2, * \mathbb{D}}$, Asfia Obaid ${ }^{1}$, Guiling Yue ${ }^{3}$, Hanieh Alipour Bazkiaei ${ }^{2} \mathbb{D}$ \\ and Noor Azam Samsudin ${ }^{4}$
}

check for

updates

Citation: Mujeeb, Tasmeer, Noor Ullah Khan, Asfia Obaid, Guiling Yue, Hanieh Alipour Bazkiaei, and Noor Azam Samsudin. 2021. Do Servant Leadership Self-Efficacy and Benevolence Values Predict Employee Performance within the Banking Industry in the Post-COVID-19 Era: Using a Serial Mediation Approach. Administrative Sciences 11: 114. https://doi.org/ 10.3390/admsci11040114

Received: 11 August 2021 Accepted: 22 September 2021 Published: 14 October 2021

Publisher's Note: MDPI stays neutral with regard to jurisdictional claims in published maps and institutional affiliations.

Copyright: (c) 2021 by the authors. Licensee MDPI, Basel, Switzerland. This article is an open access article distributed under the terms and conditions of the Creative Commons Attribution (CC BY) license (https:/ / creativecommons.org/licenses/by/ $4.0 /)$.
1 Department of HRM, NUST Business School, National University of Sciences and Technology, Scholars Ave, H-12, Islamabad 44000, Pakistan; tasmeer.mhr18nbs@student.nust.edu.pk (T.M.); asfia.obaid@nbs.nust.edu.pk (A.O.)

2 Faculty of Entrepreneurship and Business, Universiti Malaysia Kelantan (UMK), Kota Bharu 16100, Malaysia; louie.utm.20@gmail.com

3 School of Human Resource Development \& Psychology, Universiti Teknologi Malaysia, Johor Bahru 81310, Malaysia; guiling-1994@graduate.utm.my

4 Faculty of Business \& Accountancy Universiti Selangor (UNISEL), Shah Alam 40000, Malaysia; nazam@sahabat.my

* Correspondence: noorullah@umk.edu.my

Abstract: Globally, the COVID-19 pandemic has brought significant implications to the workplace and highly impacted employee performance in every organization. In contemporary research, the scholars agree that leadership is one of the critical antecedents to predict employee performance in organizations. However, research is needed to investigate the mediating role of integral factors such as benevolence values (BV) and self-efficacy (SE) in predicting employee performance in the workplace. This study aimed to investigate the impact of key antecedents on employee performance in the banking industry. The findings reveal that the key antecedents, e.g., servant leadership (SL), self-efficacy (SE), and benevolence values (BV), have a direct positive relationship with employee performance (EP). Moreover, multiple indirect paths were tested, including serial mediation. This study used a quantitative methodology based on the positivist paradigm. A sample of 560 employees was randomly chosen. A survey questionnaire was distributed among them, and 400 were returned with a response rate of $70 \%$, and the clean data of 400 employees was used for data analysis. The structural equation modeling (SEM) technique was employed using Smart PLS 3.3.3 software. The results confirmed that both SE and BV mediate the relationship between SL and EP. Likewise, BV mediates the relationship between SE and EP, and SE mediates the relationship between SL and BV. Finally, in serial mediation, the relationship between SL and EP is also established via SE and BV together as mediators.

Keywords: employee performance (EP); servant leadership (SL); self-efficacy (SE); benevolence values (BV)

\section{Introduction}

At the start of the 21st century, academic literature identified the "black box" in leadership and employee performance. Nonetheless, the present circumstance has changed as various studies currently address this issue, giving evidence of employee performancerelated factors (such as organizational commitment, organizational citizenship behavior, employee satisfaction, etc.) as mediating factors that clarify the impact of leadership on employee performance (Harwiki 2016; Setyaningrum et al. 2017). Large numbers of these investigations consider employee performance as the reliant variable since this is a key proximal result reflecting practices heavily influenced by employees and assisting in accomplishing organizational objectives/goals. 
Leadership is a component that extensively affects the proficiency of employees and managers (Buil et al. 2019; Iqbal et al. 2015). The leadership styles and employee performance had a causal connection towards the achievement of an association, depending on the different behavioral variables. It came about that leadership and performance have both immediate and intersectional relationships (Vigoda-Gadot 2007). Servant leadership can significantly improve employee performance and would help to make exceptional progress and success (Setyaningrum and Pawar 2020). Consequently, the research studies additionally presume that organizations need to focus on leadership style to improve employee performance (Tripathi et al. 2020). Ekhsan and Aziz (2021) clarified the use of the partial least square (PLS) model, which means that servant leadership can assume a noticeable part in boosting employee performance.

Instances of pneumonia diagnosed with a vague reason were recorded by the World Health Organization (WHO) in Wuhan, China, on 31 December 2019. On 7 January 2020, the Chinese specialists tracked down a new COVID virus, allegedly called "2019-nCoV". COVID (CoV) incorporates a broad scope of infections that cause sicknesses from colds to more outrageous conditions. Once more, the new strain, which was not recently recognized in people, addresses a novel COVID $(\mathrm{nCoV})$. The new infection was subsequently called the "Coronavirus infection" (World Health Organisation 2020). Virtually every country on the planet, including Pakistan, was influenced by COVID-19. The principal COVID-19 case was detected in Pakistan in Karachi on February 26, 2020. Its quick spread was inconceivably concerning. In light of the World Health Organization's (WHO's) measurements, around 215 countries, like Pakistan, were influenced by this virus. While thinking about everyday factual information on the number of episodes, the spread of COVID-19 in Pakistan was created.

Amidst the COVID-19 pandemic, many organizations lessened employee compensation or fired their employees to maintain financial stability (Almeida and Santos 2020). Then, at that point, many occupation openings were shut because numerous businesses went bankrupt. These things affected the employee's aims to leave their organization (Baum et al. 2020). Individuals continued to have adverse reactions to survive in the COVID19 pandemic circumstances (COVID). Important things were how they and their family stayed healthy, while not being pressured, and meeting their daily needs (COVID). Leadership style truly helps to make the workplace ideal in articulating the excellence of the vision and in increasing the performance of the employee and the organization (Yanney 2014). Managers are encouraged to reliably work on viable correspondence and cooperation competency (Hidayat et al. 2021).

The extreme changes influenced employee emotions (Leyer et al. 2021). The critical issue is the way to deal with the feelings that emerge into sound energy for the organization's advantage. The services of organizations that are going through changes need to screen the degree of employee job satisfaction. Job satisfaction is essentially identified with the degree of services and the employee's performance (Charalambous et al. 2018). During the time spent on changes, the company needs change-situated services. It is an essential factor in deciding the accomplishment of progress. The leaders' ability is tested from the start of the cycle, starting from empowering steps and initiating change, to making continuous improvements by assessing and changing the work interaction to be more versatile, and especially reassuring development all through the cycle since it is demonstrated to positively impact on work performance (Mikkelsen and Olsen 2019).

Despite the pertinence of the previously mentioned commitments, empirical investigations in the literature mediating and moderating the role of the individual variables in the relationship between servant leadership and employee performance are divided in terms of theories and points of view, which involves the testing of explicit interceding and directing factors (the leader's gender, organizational commitment, and self-esteem), yet not in others (Lemoine and Blum 2021; Setyaningrum et al. 2017; Xiongying and Boku 2021). Without a doubt, few examinations have considered a few mediating factors, which makes it hard to acquire a more extensive perspective on these transitional mechanisms. 
Focusing on servant leadership needs to receive further legitimacy compared to mainstream leadership theory. Chiniara and Bentein (2018) encourage researchers to investigate the impact of servant leadership, as well as individual outcomes such as individual performance or employee performance.

Better employee performance management is imperative to enhance organizational performance and effectiveness (Stanton and Pham 2014). Different methodologies are used to examine the employee performance variable, e.g., Delmas and Pekovic (2018) used a qualitative comparative analysis (QCA) methodology to see how employee performance considers employee productivity. A case study on the Bonjus and Khatib \& Alami companies show the impact of the training given to the employee, which increases their performance on the job and increases the company's overall performance (Halawi and Haydar 2018). Ponta et al. (2020) studied public administration (PA) to address monetary incentives, and their impact on employees' performance. As the study was conducted in Italy, where the stimulus is given according to the performance of the employee, a positive and significant impact was found in the short, middle, and long term. Research on both transactional and transformational leadership studied employee performance and shows a more significant relation, but are more linked with transformational leadership (Paracha et al. 2012).

As mentioned before, previous research is enriched with group performance or team performance, and individual outcomes are focused on comparatively less. Further, individuals having differences in personality traits and personality values could also constitute influential moderators. Therefore, Sun and Shang (2019) respond to the call of Liden et al. (2014b) by examining the individual characteristics of servant leadership. Further research suggests that it is necessary for future studies to incorporate personal characteristics and personality values, thereby empowering researchers to assemble a total nomological net for understanding servant leadership. Current research will fill the gap between the personality values on servant leadership style and employee performance.

Commercial banks in Pakistan offer financial help to the general populace and businesses, ensuring monetary and socially consistent quality and the attainable advancement of the economy; notwithstanding, business banks are not confined to local financial services. Commercial banking has gone through significant changes in recent times. There were dramatic administrative changes, the expansion and reconciliation of worldwide monetary business sectors, and markets and establishments have opened new doors and difficulties for commercial banking. These regulatory changes enable commercial banks to service many kinds of financial market activity. The banking system plays a crucial role in the Pakistani financial system (Ali et al. 2021). The working environment of Pakistani banking sectors saw substantial transformations during the past two decades. In recent years, Pakistani banks have moved their financing from the government to the private sector. Pakistan's financial industry is going through several changes. New organizations, for example, are buying out Pakistani businesses of several international banks. As a result, the number of listed banks is growing (Saad et al. 2021). These transformation events have an impact on the banking sector's profitability drivers. Pakistan's banking industry is the third most significant contributor to the country's economy. The services sector contributed more than half of the economy's GDP. At the end of 2020, the banking sector had a rate of $18.6 \%$, far over the required $11.5 \%$. The COVID-19 epidemic threw the economy into disarray, and the financial industry is still struggling to get back on track (Zhiqiang et al. 2021). In such a situation, enhancing employee performance enhances organizational performance (Saleh et al. 2020).

The paper is organized as follows. The first section provides an introduction, followed by research significance and objectives. The following research model (see Figure 1) based on the theoretical foundation is discussed. The second section discusses the literature on each variable, e.g., employee performance, servant leadership, employees' self-efficacy, benevolence values, and proposed hypotheses. The development of the hypotheses is 
followed by the research methods. Last but not least, data analysis and the interpretation of results are explained. Lastly, this paper discusses findings and limitations.

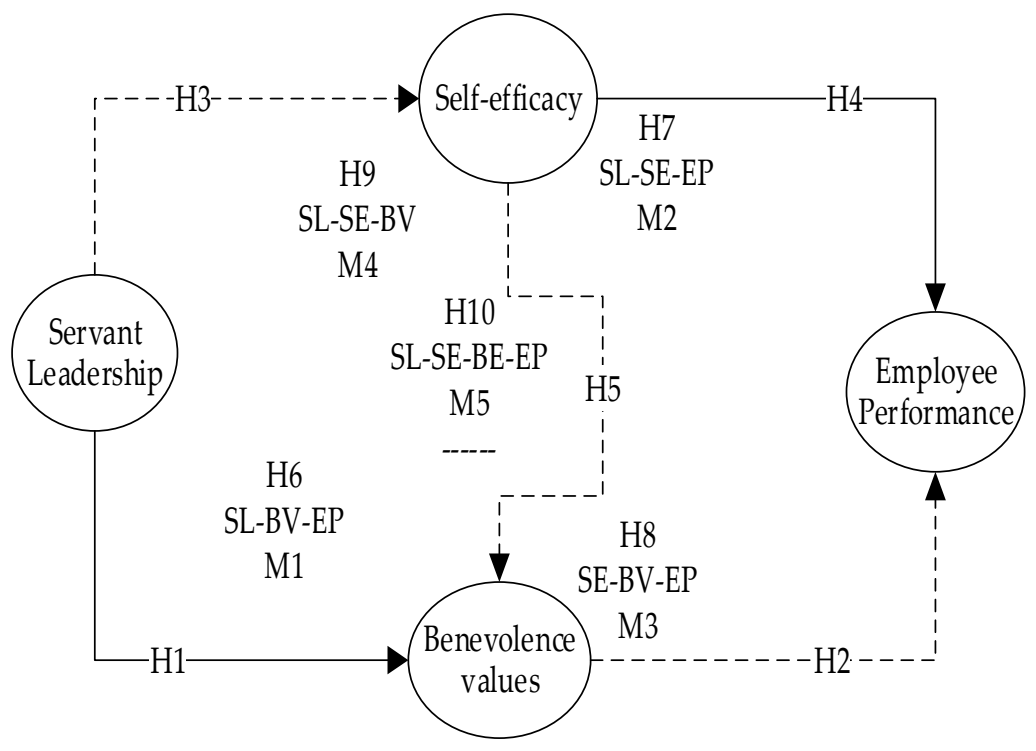

Figure 1. Research model.

\subsection{Research Significance}

Research studies contribute to theoretical and managerial implications. From the theoretical ramifications' point of view, earlier examinations have researched the role of rewards, organizational culture, employee prosocial motivation as mediating, and religiosity as moderating pathways through which servant leadership affects employee performance (Abbas et al. 2020; Sihombing et al. 2018; Stollberger et al. 2019). This examination theoretically adds to the prospering literature on servant leadership by empirically testing the fundamental mediating mechanism of leaders' benevolence values and employee self-efficacy in the relationship between servant leadership and employee performance.

The vital takeaway of this investigation for leaders is that they ought to understand that their remarkable leadership style in the work environment influences employee performance. Leaders can use their leadership style in improving organizational performance and employee performance. Moreover, this research brings important theoretical and practical implications for financial industry experts and behavioral researchers.

\subsection{Research Objectives}

- To test the indirect effects of self-efficacy on the relationship between servant leadership and employee blacksquare.

- To test the indirect effects of benevolence values on the relationship between servant leadership and employee performance.

- To test the serial mediation of self-efficacy and benevolence values on the relationship between servant leadership and employee performance.

\subsection{Research Model and Theoretical Foundation}

The purpose of the research model is to outline the critical relationships between study variables and represent the primary research idea. The current research model comprises four crucial constructs as follows: (1) employee performance as regressing variable, (2) servant leadership as regressors variable, (3) self-efficacy, and (4) benevolence value intervening variable (see Figure 1).

Social identity theory (Tajfel 1978) explains that servant leaders consider subordinates a crucial part of the organization and focus on building an authentic bond. The employee needs to recognize their self-identify and engage in behavior that will ultimately increase the individual, team and organizational worth (Chen et al. 2015). Moreover, it positively 
impacts followers' identification and employee voice (Chughtai 2016) and reduces servant leaders' burnout (Rivkin et al. 2014), and enhances organizational citizenship behavior OCB (Yoshida et al. 2014). Behavioral theories, e.g., social exchange theory and social learning theory, have provided an essential base for conceptualizing servant leadership, and they can enable leaders to transform their followers' behavior. Building the argument based on the work of Greenleaf (1991), servant leaders are more inclined towards modifying their follower's behavior. Researchers have contended that leaders have a significant impact on their supporters, altering devotees' mindsets and practices.

\section{Literature Review on Study Variables}

This section reviews the literature on endogenous variables, including (i) employee performance, and their three dimensions, e.g., task performance, contextual performance, and adaptive performance. Next, (ii) servant leadership as exogenous variable, (iii) selfefficacy, and (iv) benevolence value as endogenous mediating variables.

\subsection{Employee Performance}

Performance is an individual's general result or accomplishment during express events of responsibility that stand apart from the work norm. The literature on performance consists of both contrary and supportive evidence, but significant progress has made in this regard as well (Zainal 2004). Zainal further concludes that performance does not stand in isolation in connection with work fulfillment and pay, but is also affected by various antecedents, including individual characteristics. Employee performance (EP) is directed by the limit, need, and condition. EP is linked with progression, and these associations are most likely required for successful people or high achievers' laborers.

$\mathrm{EP}$ is vital in deciding the accomplishment of organizational objectives and missions. Consequently, companies search for approaches to motivate workers and improve their performance at work. However, EP has been thoroughly investigated in the western context. However, there has been very little research exists on measuring EP, such as contextual performance adaptative performance and task performance in the Pakistani context. Significant management literature suggests that EP can be predicted by various antecedents (Ali et al. 2020; Khushk and Works 2019; Yan et al. 2020).

Over decades, EP has been explored in various settings across the world in different industries and societies to enhance existing practices, ideas, in achieving ideal solutions (Bono and Judge 2003). Integrating findings on best practices can improve performance and empower organizations to utilize resources for workers' physical, psychological betterment, to enhance their enthusiastic capacities (Pham-Thai et al. 2018). Innovative practices like (IWB) (Pham-Thai et al. 2018), personal and group learning positively contribute to job performance (Sun et al. 2017), and enhance OCB (Hermawati and Mas 2017), and the relationship between leader and followers based on leader member exchange (LMX) Theory. (Zhang and Bartol 2010) have critically discussed direct and indirect factors that are drawing in academic consideration for advancing hierarchical effectiveness, execution, and development. Various research surveys have been conducted on employee performance and the defining factors in academic literature. These surveys primarily concentrate on job demand, assets and stressors (Pandey 2019), and mobile-banking, respectively (Tam and Oliveira 2017). In the current research, the employee performance is measured with three dimensions, including task performance, contextual performance, and adaptive performance.

\subsubsection{Task Performance}

Task performance (TP) is defined as "the proficiency with which job incumbents perform activities that are formally recognized as part of their jobs; activities that contribute to the organization's technical core either directly by implementing a part of its technological process, or indirectly by providing it with needed materials or services"(73) (Borman and Motowidlo 1993). TP is the capability with which officeholders perform tasks that are 
officially perceived as a component of their positions, exercises that add either directly or indirectly to an organization. Budhwar and Chandrakumara (2007), on the other hand, conclude that worker TP includes activities that are part of the conventional expected set of responsibilities. In this way, it implies work explicit undertaking capability, specialized capability, or in-job performance.

\subsubsection{Contextual Performance}

The origin point of contextual performance $(\mathrm{CP})$ can be followed back to the research of Brief and Motowidlo (1986), who introduced the possibility of significant prosocial behavior in organizations. Borman and Motowidlo (1993), describe CP as discretionary behaviors that apply across all jobs, are not necessarily role prescribed, and that contribute to the social and psychological environment of the organization. Campbell (1990) has proposed that task execution can be divided into two separate classifications (i) task performance and (ii) contextual performance. $\mathrm{CP}$ refers to those practices that establish work and related with the creation supportive climate, such as involving in extra or difficult work, keeping up excitement at work, helping out others and sharing data and other basic resources. Contextual activities can be part of all basic positions and are less job recommended in most cases. These activities support the hierarchical, social, and mental climate in which task performances are conducted. It also includes behaviors such as volunteering, helping, persisting, etc., that are more likely anticipated by volitional factors identified with singular contrasts in persuasive qualities and inclination or individual organization fit.

\subsubsection{Adaptive Performance}

Adaptive performance (AP) can be discussed based on various definitions, viewpoints and conceptualizations (Baard et al. 2014). Jundt et al. (2015) have provided better understanding and describes AP as conduct coordinated effort of task performance that result in changes an influence work-related outcomes. According to Johnson (2001), AP is an individual's ability to adjust him/herself in a constantly changing work environment by modifying conduct, accepting new and innovative situations. Similarly, Griffin et al. (2007) have tried to link adaptive performance with training in the workplace. Likewise, Charbonnier-Voirin and Roussel (2012) have declared that individuals need the capacity and status to include themselves in learning new skills. AP alters an individual attitude and behavior to address the hierarchical change, and it happens essentially through adjusting to the new work requirements.

\subsection{Servant Leadership}

Previous literature has thoughtfully recognized servant leadership (SL) from different leadership styles, e.g., transformational leadership (Barbuto and Wheeler 2006; Stone et al. 2004). Van Dierendonck (2011) has presented this view in his work that servant leadership varies from the other recognized leadership styles, looking into the differences between several leadership types. In comparison with transformational leadership (TL), the SL style is increasingly centered around the psychological needs of followers as an objective in itself, while transformational puts these requirements discretionary to the organizational goals (Van Dierendonck et al. 2014). In a broader context, literature primarily supports two leadership styles, i.e., servant and transformational, as both have received significant attention from scholars. However, there are subjective and comparative differences between these styles among scholars.

When we talk about transformational leaders' thought processes, they prefer to concentrate on followers' needs, to empower them in accomplishing authoritative objectives more readily. In contrast to this, servant leaders' primarily want to serve first and focus on followers' development. Stone et al. (2004) have suggested that hierarchical objectives are just a side-effect accomplished over a long haul of a purposeful spotlight on followers' needs. Based on this discussion, SL followers have a more prominent probability to be served first in comparison with TL followers (Sendjaya 2016). The servant-style considers 
giving free depictions of what, why, and how style carry on towards their supporters as they do. Greenleaf first coined the concept of SL in his essay titled "The servant-leader is servant first. It begins with the natural feeling that one wants to serve, to serve first. Then conscious choice brings one to aspire to lead. That person is sharply different from one who is leader first, perhaps because of the need to assuage an unusual power drive or to acquire material possession. The leader-first and the servant-first are two extreme types. Between them there are shadings and blends that are part of the infinite variety of human nature".

Endeavors to characterize SL dependent on its results (for example, organizational citizenship behavior), models (for instance, benevolent behavior), or less significantly, predecessors (for example, character) have brought about clarifications possibly too tangled to be helpful for the two researchers and professionals. Remembering this, another significance of SL, elaborated as (i) SL is an approach to manage organization (ii) through one-on-one individual interactions to meet requirements and interests, and (iii) mitigating anxiety and stress of followers and enhance employee and organizational performance.

The aforementioned discussion has three features that explicitly make up the substance of SL, its intention, style, and attitude. In any case, the reasoning of SL (for instance, 'otherorganized approach to manage authority') does not start from inside yet outside the pioneer, as the hidden 'specialist first' seems to suggest. Essentially, and it changes mind consistently, the motivation behind Greenleaf is that he gave his booklet the title: 'the servant as leader,' not 'the leader as servant.' Considering everything, an essential piece of servant leadership, and where it isolates itself from various organizational perspectives, is the secret individual motivation for taking up a power obligation. This course towards others reflects the pioneer's motivation, conviction, or conviction that pushing others suggests an advancement away from self-heading.

\subsection{Self-Efficacy}

Self-efficacy (SE) refers to a person's confidence in their capacity to accomplish a constructive result from an undertaking or movement (Bandura 2012). SE has three measurements parameters, e.g., (i) magnitude applies to the degree of assignment difficulty that an individual accepts the person in question can achieve. Secondly, (ii) strength alludes to whether the conviction concerning greatness is strong or weak. Generality demonstrates how much the desire is summed up across circumstances (Bandura 1977). Bandura et al. (1977) have underlined that SE behavior must be estimated absolutely in examining adequacy and that measures should be custom fitted to the space being considered. It is critical to concentrate on explicit undertakings and to evaluate adequacy recognition and execution over a scope of expanding task trouble. Bandura's measures represent a microanalytic research approach and survey the quality, extent, and all-inclusive statement of self-viability. Banduras has explained that individual SE interprets data from four sources: (i) mastery experience, (ii) vicarious experience, (iii) social persuasions, and (iv) physiological states. The most compelling of these four sources is mastery experience (Bandura 1997). Mastery experience results from an individual participating in an undertaking and accomplishing what they see as a positive result. This experience of dominance prompts expanded understandings of their abilities incomparable performances (Zelenak 2015).

People with such beliefs are certain about their ability to adapt to issues and effectively search for better approaches to perform complex assignments and difficulties. The study conducted by Aguilar and Yuan (2010) additionally affirmed that supervisors with low selfefficacy need belief and neglect to deal with business activities adequately. Moreover, it is believed that profoundly compelling individuals are relied upon to utilize everything and are ready to create assets in their workplace to manage difficult assignments. Essentially, researchers have concluded that individuals with high levels of self-efficacy are better at tackling issues as compared to an individual with low degrees of belief. Thus, in light of the abovementioned hypothetical confirmations, it very well may be presumed that 
self-efficacy is a fundamental individual belief that is conceivably useful in employee performance.

\subsection{Benevolence Values}

Individual values are originations of attractive end expresses that reflect what is imperative to us in our lives (Feather 1990, 1995). For instance, an individual may consider herself as an individual who values equality and social equity. The traditional method to satisfy these qualities is by carrying on in manners that express them, by dedicating time to improve the lives of others. Although various empirical investigations bolster a value-behavior relation (Schwartz 2013), the changeability in the size of this relationship across different worth spaces proposes that its quality might be affected by encouraging or impeding factors (Bardi and Schwartz 2003). Schwartz has recognized ten unique kinds of values that are discernable by individuals in many societies (Figure 2).

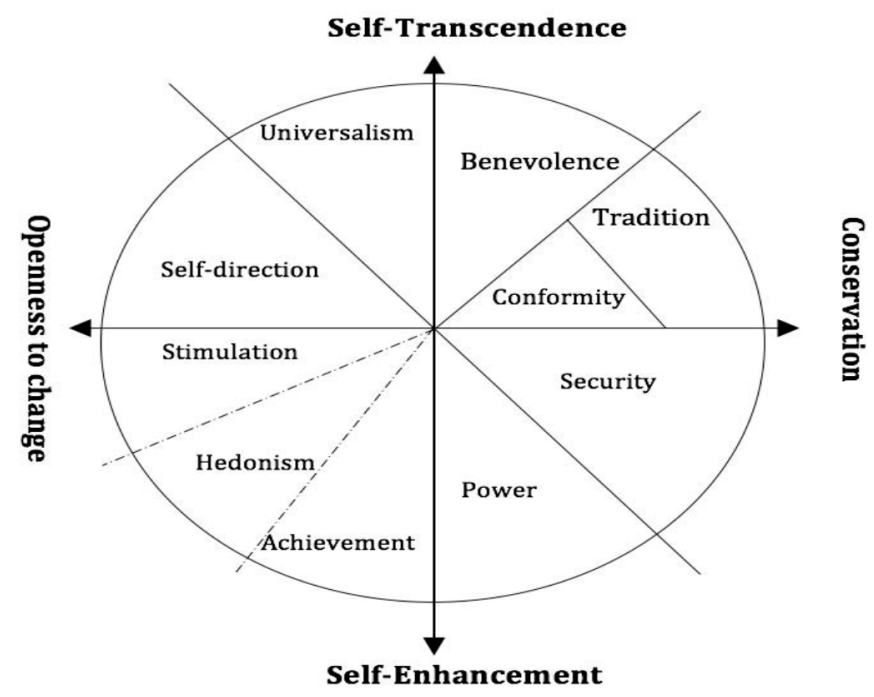

Figure 2. Schwartz's model of motivational types of values Source: Bardi and Schwartz (2003).

Loving one's fellow people benevolence is a fundamental concept in a value belief system. The leader carrying benevolence values cares about people. Love your fellow people, the benevolent leader takes good care of their followers needs and helps them to achieve their goals. A great leader appreciates their followers and can choose the right person for right job (Schwartz and Rubel-Lifschitz 2009) Benevolence preservation and enhancement of the welfare of people with whom one is close is helpful, caring, loyal and supportive. These characteristics, e.g., being humble, uprightness, persistent, simplicity, and honesty, are very close to benevolence. On the other hand, decorated words such as flattery and smooth talk rarely reach the realm of benevolence.

To be humble is thus suitable. Humbleness is the basis of servant leadership. The leader is to serve their people. It is better to be benevolent, doing a little kindness near or at home, than go far away to burn anger (DeYoung 2020; Otto et al. 2021). Being centered; everyone can attempt to do good and do all kinds of kind actions and small acts with significant consequences. Additionally, these include helping a coworker succeed, cheering a coworker who is down or having problems, helping others be a better team player, and infecting others with happiness. The literature considers benevolence to be a good main characteristic (Sun and Shang 2019). Research has firmly acknowledged that one should make it one's core value to do one's best for other people and be dependable in what one says. According to Page et al. (2021), leaders should incorporate benevolence, kindheartedness, and other-centeredness; and deal with their subordinates like relatives and give them consideration, direction, training, and support, since one should be respect- 
ful and cooperate with other individuals or groups calmly, incongruity and with a feeling of solidarity.

\subsection{Servant Leadership with Employee Performance}

Empirical investigations have confirmed the effect of servant leadership on employee performance. The previous studies have revealed the relationship between leadership style other key variables, e.g., job satisfaction (Mayer et al. 2008), organizational commitment, turnover intention (Hunter et al. 2013), and innovation (Neubert et al. 2008). While research has already established a direct relationship between servant leadership and employee performance (Liden et al. 2008), little is known about factors that can explain this relationship through mediating mechanisms (Liden et al. 2014a). Several studies have demonstrated a relationship between servant leadership and task performance either at unit or individual level (Neubert et al. 2008). Further, little research has inspected the relationship between servant leadership and three dimensions of individual employee performance as sub constructs, e.g., task performance, adaptive performance, and contextual performance. Recognizing these three dimensions are significant because the earlier research has revealed that performance can be measured through multiple dimensions (Van Scotter et al. 2000).

Servant leadership depends on the reason that servant leaders build trust by benevolently concentrating on serving followers' needs; they can construct reliable relationships that will, in general, draw out the best in the entirety of their supporters. Understanding the knowledge of followers' needs can enhance their abilities (Liden et al. 2008). Servant leaders putatively enable followers' commitment in accomplishing group task performance objectives and strengthen the group's critical thinking abilities that are essential for viable teamwork, and thus positively impact task performance (Liden et al. 2008, 2014a). These ongoing collaborations between servant leaders and colleagues decrease representatives impression of contrasts in relationship quality with their pioneer. As servant leaders worth and fabricate trust in all colleagues, it limits the production of sub-gatherings. In this way, it actuates followers to strengthen ties, connect with and participate vigorously to achieve assignments, and subsequently upgrade the group union. Servant leadership appeared to help fulfill psychological needs, prompting commitment (Van Dierendonck et al. 2014). Servant leadership categorically predicts influence-based trust in the followers and improves group-level performance. In conclusion, for example, the common faith in aggregate capacities intervenes in the connection between worker initiatives and group task performance.

Servant leaders share their shrewdness, create understanding, and grant it to followers (Russell and Stone 2002). This shows that they attempt to convince their subordinates instead of constraining them to complete judgment or utilizing manipulative techniques (Van Dierendonck 2011). For example, in their conversations with subordinates, servant leaders act with integrity and show consistency in actions and morality; and be true to themselves and the spirit of the leadership principles they preach (Van Dierendonck et al. 2014). Servant leaders delegate authority to their subordinates and enhance their development (Van Dierendonck 2011). They center around stewardship (for example, social obligation), giving guidance (for example, providing the correct level of responsibility), demonstrating relational acknowledgment (for example, compassion), and being genuine (for example, keeping guarantees). Humbleness, which centers around putting representatives' inclinations first, is an essential component of servant leadership. As highlighted by Van Dierendonck (2011), working from a need to serve does not suggest a disposition of servility, as the force lies in possession of followers. Hoch et al. (2018) have further described that the relationship between authentic leadership and adaptative performance $r=(0.12)$ was less than the relationship between servant leadership and adaptative performance (0.23).

Bass (1985) has revealed that transformational leaders communicate the organizational vision persuasively and convince their followers to apply extra effort in work. Similarly, past studies have confirmed a favorable effect of transformational leadership on additional 
job practices (Piccolo and Colquitt 2006). Very few studies have investigated the effects of TL on CP (Judge and Piccolo 2004). This lack of research on CP can be attributed to the significant amount of research on task performance, which is considered an integral part of job responsibilities (Podsakoff et al. 1996). In a similar manner, this gap of literature has been explained by Borman and Motowidlo (1993), that literature experts have given more attention to task performance than CP. Based on previous literature current study focuses on employee performance as endogenous variable, measuring it with three dimensions, e.g., task performance, adaptive performance, and contextual performance.

\subsection{Servant Leadership with Benevolence Values}

The literature on leadership shows the conflicting view between the two leadership styles, e.g., servant leadership (SL) and transformational leadership (TFL), that have differences and similarities. Van Dierendonck et al. (2014) concluded that both SL and TFL were associated with organizational commitment, performance, and job commitment. In spite of their differences and similarities, SL works essentially advocate follower need fulfillment, while TFL predominantly supports initiative viability.

Egri and Herman (2000) have conducted a study based on the meeting. The survey acquired data from 73 leaders of for-profit organizations. The result has shown that these leaders' very own qualities were more eccentric, open to change, and self-transcendent than directors in different organizations. These leaders or managers were routinely performing both types of leadership styles, e.g., transformational and transactional leadership. As hypothesized, nonprofit environmentalist organizations were highly receptive contexts for transformational leadership, whereas for-profit environmental organizations were at least moderately receptive in this regard.

Fu et al. (2010) believed that personal values, especially self-transcendence worth direction, are a significant part of transformational leadership and help to explain transformational leadership constructs. Based on the literature, the study hypothesized these constructs. The study further explains that the two personal values, e.g., self-transcendence benevolence and universalism, positively impact transformational leadership (Morrison 2018).

Hypothesis 1 (H1). Servant leadership has a positive relationship with benevolence values.

\subsection{Benevolence Values with Employee Performance}

As indicated by Schwartz (1994), values are mixed into individuals' effects and feelings. They can deliver explicit attractive objectives of being among individuals. Accordingly, they rise above explicit activities and practices. Individuals may hold various qualities with changing levels of significance (Schwartz 2012). Self-transcendence quality qualities are credited to benevolence and universalism. These two qualities start from the requirement for relationship and endurance (Schwartz 2012). Benevolence and universalism cause general emotional practices of worry for other people, society, climate, and unselfishness.

Consequently, Cannavale et al. (2020) have investigated the impact of benevolence on performance, and explained leader personal values, such as "core values throughout everyday life". Schwartz (2012) has investigated the influence of enterprise practices at the hierarchical level through essential dynamic perceptions (Richard et al. 2009). The result has confirmed a positive relationship between CEO other-direction values and employee orientation towards performance. Based on the previous literature, this study hypothesized the relationship between benevolence value and employee performance.

Hypothesis 2 (H2). Benevolence values have a positive impact on employee performance.

\subsection{Servant Leadership with Self-Efficacy}

According to Schyns' (2001) research, a positive relationship between transformational leadership and occupational self-efficacy has been confirmed. Similarly, Gong et al. (2009) 
have explained the relationship between a supervisor's leadership style, specifically TL, and employee self-efficacy. Study results demonstrate the significant and positive impact of TL on employee self-efficacy. Felfe and Schyns (2006) have focused on occupational self-efficacy and tend to recognize the importance of transformational supervisors' leadership. Several researchers have studied self-efficacy with servant leadership in different sectors, showing self-efficacy's positive effects on performance (Haider and Mushtaq 2017; Kwon and Kang 2017; Song and Kwon 2017; Walumbwa et al. 2010). According to the aforementioned findings, the following hypothesis is proposed.

Hypothesis 3 (H3). Servant leadership has a positive impact on self-efficacy.

\subsection{Self-Efficacy with Employee Performance}

Self-efficacy is an individual's faith in their capacity to create and make accomplishments by evaluating experience. This belief drives people to perform sufficiently and adapt to circumstances experienced in a usual manner (Bandura and Walters 1977). Self-efficacy impacts on close to home conduct as the way toward suspecting, inspiration and feeling. Bandura (1986) expressed that self-efficacy drives an individual to pick behavior identified with their capacity to accomplish something. This individual likewise exhausts exertion and ingenuity to acquire or achieve the ideal objective. An individual with high self-efficacy is bound to perform specific practices with the exclusive standard.

On the other hand, an individual with low self-efficacy will probably perform at lower desire levels (Yusuf 2011). Carter et al. (2018) and De Clercq and Haq (2018) have proposed that SE affects employee performance emphatically at individual and hierarchical levels. Workers with high self-efficacy are sure and propelled to work well, as anticipated by the supposition of the framework hypothesis that input impacts yield. Stajkovic et al. (2018) have founded that workers with high levels of self-efficacy is more averse to abandon the quest for their duties. Recently Pratiwi and Nawangsari (2021) have studied the relationship between self-efficacy and employee performance using partial least square (PLS) results confirms a positive relationship between self-efficacy and employee performance. Based on these findings, this study hypothesized the following relationship.

Hypothesis 4 (H4). Self-efficacy has a positive relationship with employee performance.

\subsection{Self-Efficacy with Benevolence Values}

Personal values in relation to empathic self-efficacy convictions are positively related. The stronger the relationships between openness to change and self-efficacy and personal values, the more positive the impact on self-transcendence and teachers' self-efficacy (Barni et al. 2019; Caprara and Steca 2007).

Caprara and Steca (2007) have analyzed an estimated model in which self-efficacy and personal values such as self-transcendence include the benevolence values and universalism values and advance prosocial conduct. The research results have highlighted significant fluctuation in prosocial behavior, from $41 \%$ to $70 \%$ in the two genders. Results have confirmed the impact of personal values, especially transcendence, on self-efficacy. In their recent study, Kim and Park (2020) have identified that self-transcendence, which includes both values, mediated the relationship between self-efficacy and life satisfaction. While self-efficacy was significantly positively correlated with self-transcendence values. This study, based on the previous literature, hypothesizes the following relationship.

Hypothesis 5 (H5). Self-efficacy has a positive relationship with benevolence values.

\subsection{Self-Efficacy and Benevolence Value as a Mediating Variable}

Personal values may improve work meaningfulness by giving direction associated with all life and work perspectives. People may discover their life reason through close to personal objectives (Grant 2008). Others may feel called to satisfy a personal values reason that gets enduring and profound seriousness three different ways. In the first place, indi- 
vidual self-transcendence asks, "what would I be able to contribute?" Servant leadership increases job meaningfulness through enhancing newcomers' values of self-transcendence (Jiang et al. 2015). Research studies have reported the impact of self-transcendence on altruistic behavior as a mediating variable. The results from structural equation modeling supported the hypothesized model (Dagar et al. 2020).

Hypothesis 6 (H6). Benevolence values mediate the relationship between servant leadership and employee performance.

Servant leadership explains the changes in frontline employees' performance behaviors. Representatives' self-personality and self-efficacy mediated the relationship between servant leadership and service performance behaviors (Chen et al. 2015). This is a study with a broader explanation, indicating that individuals with consistent self-belief convictions are more equipped to take care of tasks and give more prominent exertion when confronted with challenges, prompting predominant performance (Chen et al. 2007). The literature explains that employees with strong self-efficacy also have more sure effects at work, and regularly identified with citizenship practices coordinated at clients (Peng et al. 2016). In addition, employees with more productive beliefs are prone to go beyond typical job requirements, take the initiative, and be spontaneous and innovative in serving customers, all of which are indicators of prosocial behavior at work. Based on the above literature, this study hypothesized the following relationships.

Hypothesis 7 (H7). Self-efficacy mediates the relationship between servant leadership and employee performance.

Hypothesis 8 (H8). Benevolence values mediate the relationship between self-efficacy and employee performance.

Hypothesis 9 (H9). Self-efficacy mediates the relationship between servant leadership and benevolence values.

Hypothesis 10 (H10). Self-efficacy and benevolence values serially mediate the relationship between servant leadership and employee performance.

\section{Methodology}

To achieve research objectives, a quantitative methodology was used. Following the positivist philosophy using the deductive approach was employed to answer the research questions. The study used a quantitative approach, and cross-sectional data were collected from the private banks, e.g., Summit Bank Limited, Al Baraka Bank, Allied Bank, Askari Bank, Bank Al Habib, Bank Alfalah, Bank of Punjab, Faysal Bank, Habib Bank Limited, Habib Metro Bank, JS Bank Limited, Meezan Bank, Muslim Commercial Bank, Samba Bank, Soneri Bank, and United Bank Limited using adopted questionnaires.

\subsection{Target Population}

Specifically, severe and fast information and correspondence innovation transformed the banking sector (Ratten 2008). Past research in the non-western context has made considerable progress in the banking sector (Kaushik and Rahman 2015). Primarily, the financial banking sector made a significant contribution to Pakistan's economy (Ul Hassan et al. 2012). The banking sector has been through transitional and extraordinary changes. It includes customer oriented innovative solutions (Kumar Behera et al. 2015). The current study aims to investigate the key antecedents of employee performance in the banking sector. The target population for the present study consisted of all permanent employees working in the private banking sector of Pakistan. The population refers to a set of individual or research objects with similar characteristics (Sekaran and Roger 2016). Employees included in this research are of a private commercial bank, which consists of the 
operational manager, business development officer, client relationship officer, customer care representative, loan officer, bank officer, customer service representative. At the time of data collection, the combined total headcount of private commercial banks working currently in Pakistan is approximately 105,666 based on the available official count.

\subsection{Sample Size}

According to Ferdinand (2006), a sample is a subset of the populace that has a true representation of the populace. Sample size plays a significant role in validating results. Ferdinand (2006) recommended that a suitable sample size for SEM examination is between 100-200. The current study sample, i.e., $n=400$, is relatively sufficient to acquire a decent proportion of goodness-of-fit. The required sample size was assessed to be 383 at a $95 \%$ confidence level with a 5\% margin of error using sampling formulas and calculator form target population frame of 105,666 employees. To avoid low response rate issues keeping the post-COVID-19 situation initially, 560 questionnaires were distributed randomly among employees of the banking sector.

\subsection{Survey Instruments}

The current research has measured employee performance (EP) construct based on three dimensions, e.g., task performance, adaptive performance, and contextual performance, using 23 items scale developed by Pradhan and Jena (2017). Servant leadership (SL) was measured by a seven-items short modified SL-7 scale by Liden et al. (2015). The benevolence values (BV) variable was measured with six items from PVQ-RR scale by Schwartz (2012) using a 5-point Likert scale. This scale shows the level of agreement and disagreement from 1 (strongly disagree) to 5 (strongly agree). Self-efficacy (SE) was measured with seven-item scale consistent with Bandura (2006) scale developed by Borgogni et al. (2010). The complete details of items are presented in Appendix A.1.

\subsection{Control Variable}

Employee position and bank type were incorporated as the control factors because of their likely critical and puzzling impacts (Babakus et al. 2003; Chan and Mak 2014; Chiniara and Bentein 2016; Shukla and Rai 2015).

\subsection{Data Collection and Response Rate}

The researcher first identifies the private banks in Pakistan and takes official permission for the survey's purpose. Survey instruments were based on SL, EP, BV, and SE, respectively. The participants were given assurance that the responses would be kept confidential. The researcher collected data from the employees working in sixteen various private banks employee. The required sample size for this population should be 383 at a $95 \%$ confidence level with a 5\% margin of error. To avoid low response rate issues keeping the post-COVID-19 situation initially, 560 questionnaires were distributed among employees of the banking sector. However, 400 questionnaires were returned, showing a $71 \%$ response rate. The survey was personally administered. Response rate above $50 \%$ acceptable and recommended for a personally administrated survey. To assess the detailed questionnaire's items (See Appendix A.1).

\section{Data Analyses and Results Interpretations}

Based on the quantitative approach, the current study employed the structural equation modeling (SEM) technique using Smart PLS 3.3.3 software. The quantitative examination contains a few stages and methods. In the first place, quantitative data was refined through specific cleaning tests and procedures. A few questionnaires had missing data that was managed using the mean imputation method. The clean data of 400 employees is sufficient for PLS-SEM analysis of estimation. PLS-SEM is broadly utilized in social sciences research (Ali et al. 2018). The PLS-SEM procedure was assessed on measurement and structural model using Smart PLS 3.3.3 software (Rezaei 2015). 


\subsection{Demographic Characteristics}

The descriptive statistics analysis reported that a total of four-hundred employees participated in this study representing various banks, e.g., Summit Bank Limited, Al Baraka Bank, Allied Bank, Askari Bank, Bank Al Habib, Bank Alfalah, Bank of Punjab, Faysal Bank, Habib Bank Limited, Habib Metro Bank, JS Bank Limited, Meezan Bank, Muslim Commercial Bank, Samba Bank, Soneri Bank, and United Bank Limited. The demographic characteristics include participant age, gender, marital status, education, overall working experience, currently employed years, organization, and position. The details about each demographic characteristic are highlighted in Table A1 (See Appendix A.2).

\subsection{Measurement Model}

To validate the measurement model, convergent and discriminant validity ought to be confirmed. The measurement model consists of four constructs, e.g., SL, SE, BV, and EP. The default estimation model was estimated through 49 items using Smart PLS 3.3.3. At first, to build up united legitimacy, three boundaries were utilized: (1) the factor loading ought to be more than 0.7 ; (2) composite reliability (CR) ought to be more noteworthy than 0.7; and (3) the worth of a standard (AVE) ought to be more than 0.5. To adjust the measurement model, around 26 items were eliminated (EP 2, EP 4, EP 6, EP 11, to EP23). The adjusted measurement model with 24 items confirmed both CV and DV (see Figure 3).

To evaluate the measurement model, first convergent validity $(\mathrm{CV})$ ought to be determined dependent on three rules: (i) the loading factor ought to be more than 0.70; (ii) composite reliability (CR) ought to be more than 0.7; and (iii) the value of (AVE) should be more than 0.5 . The discriminant validity (DV) was evaluated based on the above three parameters. The outcomes affirmed that all the three criteria were not violated (see Table 1).

Table 1. Convergent validity assessment.

\begin{tabular}{|c|c|c|c|c|}
\hline Construct & Items & Factor Loading & CR & AVE \\
\hline \multirow{6}{*}{ BV } & BV01 & 0.732 & \multirow{6}{*}{0.899} & \multirow{6}{*}{0.597} \\
\hline & BV02 & 0.807 & & \\
\hline & BV03 & 0.778 & & \\
\hline & BV04 & 0.801 & & \\
\hline & BV05 & 0.773 & & \\
\hline & BV06 & 0.743 & & \\
\hline \multirow{7}{*}{$\mathrm{EP}$} & EP01 & 0.744 & \multirow{7}{*}{0.907} & \multirow{7}{*}{0.584} \\
\hline & EP03 & 0.733 & & \\
\hline & EP05 & 0.716 & & \\
\hline & EP07 & 0.797 & & \\
\hline & EP08 & 0.826 & & \\
\hline & EP09 & 0.744 & & \\
\hline & EP10 & 0.781 & & \\
\hline \multirow{5}{*}{$\mathrm{SE}$} & SE02 & 0.704 & \multirow{5}{*}{0.865} & \multirow{5}{*}{0.561} \\
\hline & SE04 & 0.789 & & \\
\hline & SE05 & 0.761 & & \\
\hline & SE06 & 0.767 & & \\
\hline & SE07 & 0.721 & & \\
\hline \multirow{6}{*}{ SL } & SL02 & 0.705 & \multirow{6}{*}{0.910} & \multirow{6}{*}{0.628} \\
\hline & SL03 & 0.785 & & \\
\hline & SL04 & 0.808 & & \\
\hline & SL05 & 0.813 & & \\
\hline & SL06 & 0.859 & & \\
\hline & SL07 & 0.774 & & \\
\hline
\end{tabular}

Benevolence value (BV), employee performance (EP), self-efficacy (SE), servant leadership (SL).

Discriminant validity $(D V)$ was evaluated dependent on three boundaries: (1) Fornell and Lacker basis; (2) cross-loadings; (3) a heterotrait-monotrait ratio (HTMT) utilizing Smart PLS DV yield. Table outcomes affirmed that the inclining esteem in (intense) of 
each develop, for example, SL, BV, SE, and EP, is more noteworthy than the inter-construct correlation values. The loading of items should be higher than their own construct rather than other construct (See Tables 2 and 3).

Table 2. Fornell and Lacker criterion using inter correlation matrix of constructs.

\begin{tabular}{ccccc}
\hline & BV & EP & SE & SL \\
\hline BV & $\mathbf{0 . 7 7 3}$ & & & \\
EP & 0.434 & $\mathbf{0 . 7 6 4}$ & $\mathbf{0 . 7 4 9}$ & $\mathbf{0 . 7 9 2}$ \\
SE & 0.518 & 0.548 & 0.416 & 0.294 \\
SL & 0.497 & 0.676
\end{tabular}

Note: The diagonal value in bold number should be greater than inter-construct correlation value.

Table 3. Cross-loadings.

\begin{tabular}{lcccc}
\hline & $\begin{array}{c}\text { Benevolence } \\
\text { Value }\end{array}$ & $\begin{array}{c}\text { Employee } \\
\text { Performance }\end{array}$ & Self-Efficacy & $\begin{array}{c}\text { Servant } \\
\text { Leadership }\end{array}$ \\
\hline BV1 & 0.7321 & & \\
BV2 & 0.8075 & & \\
BV3 & 0.7784 & & \\
BV4 & 0.8008 & & \\
BV5 & 0.7732 & & \\
BV6 & 0.7426 & 0.7445 & \\
EP1 & & 0.7814 & \\
EP10 & 0.7326 & & \\
EP3 & 0.7165 & & \\
EP5 & & 0.7968 & \\
EP7 & 0.8264 & & \\
EP8 & 0.7444 & & \\
EP9 & & 0.7040 & \\
SE2 & & 0.7892 & \\
SE4 & & 0.7613 & \\
SE5 & & 0.7671 & \\
SE6 & & 0.7211 & \\
SE7 & & & 0.7052 \\
SL2 & & & 0.7852 \\
SL3 & & & 0.8077 \\
SL4 & & & \\
SL5 & & & \\
SL6 & & & \\
SL7 & & & \\
\hline
\end{tabular}

The heterotrait-monotrait ratio (HTMT) is the third standard for evaluating DV, and first to assess HTMT proportion. Any worth above 0.85 or 0.90 demonstrates DV, as displayed in Table 4. All the diagonal values, e.g., 0.632, should be greater than the other correlation values, e.g., 0.603 and 0.331 . Similarly, other variables' diagonal and correlation values were below the threshold limit 0.85 , in this manner affirming that DV does not exist (Kline 2011).

Table 4. Hetrotrait-monotrait ratio (HTMT).

\begin{tabular}{lllll}
\hline & BV & EP & SE & SL \\
\hline BV & & & & \\
EP & 0.477 & & & \\
SE & 0.603 & 0.632 & 0.487 & \\
SL & 0.562 & 0.331 & \\
\hline
\end{tabular}




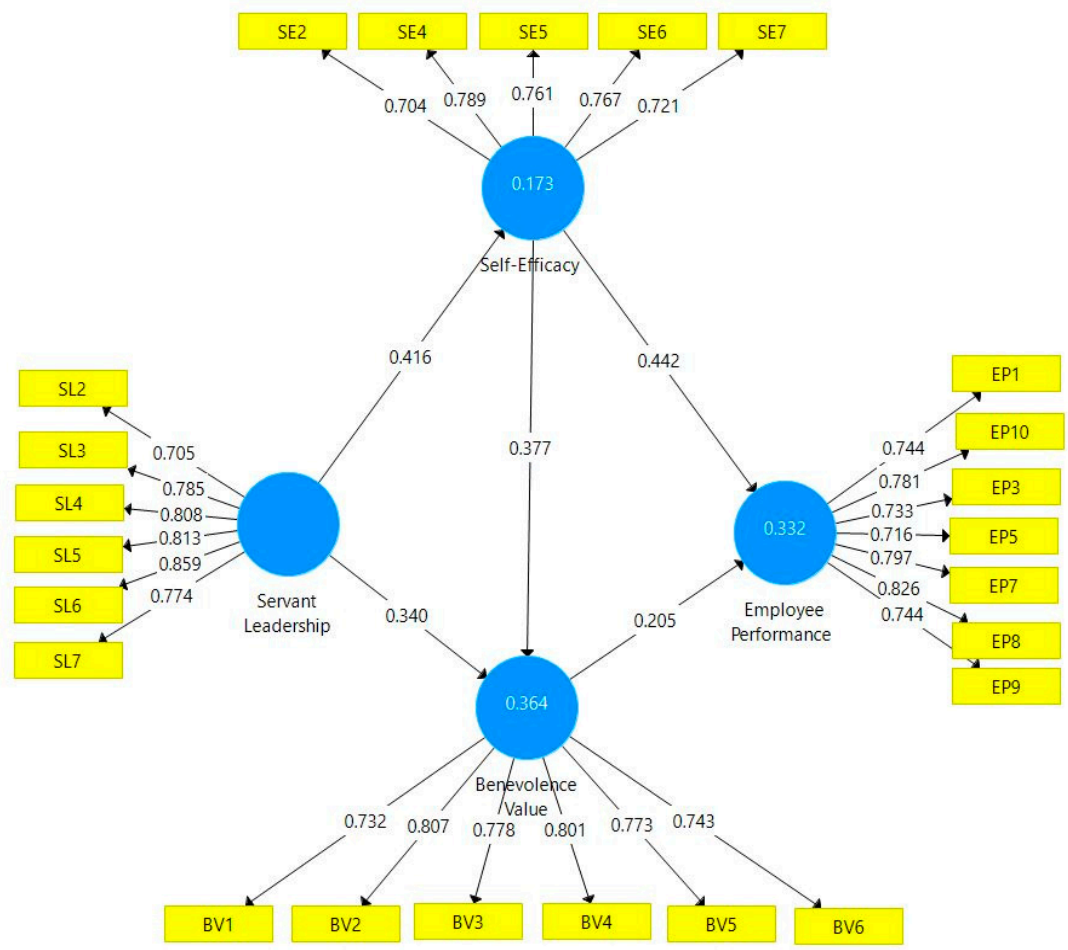

Figure 3. Adjusted measurement model.

\subsection{Assessment of Structural Model}

Once the measurement estimation model is performed, the next step is to evaluate the structural model. To do so, first, we employed collinearity assessment. Once collinearity assessment is completed next step was to assess direct and indirect effects. Variance inflation factor (VIF) values were used to evaluate multicollinearity using Smart PLS. Table 5 shows that the VIF value for EP is 1.367. The collinearity assessments result confirms that no collinearity issue existed in the model.

Table 5. Collinearity assessments.

\begin{tabular}{ccccc}
\hline & BV & EP & SE & SL \\
\hline BV & - & 1.367 & - & - \\
EP & - & - & - & - \\
SE & 1.209 & 1.367 & - & - \\
SL & 1.209 & - & 1.000 & - \\
\hline
\end{tabular}

To assess the structural model based on path coefficient $(\beta), p$-values and $t$-values were considered (Hair et al. 2014). In total, ten proposed hypotheses, i.e., (H1 to H10), were tested through SEM using Smart PLS bootstrapping procedure, see Figures 4 and 5. Moreover, Table 6 shows the result of direct hypotheses, e.g., $\mathrm{H} 1$ to H5. The result confirmed that all five direct paths were supported. The values of path coefficient $(\beta), p$-values, and $t$-values for each direct hypothesis are discussed in Table 6 below.

Table 6. Direct effects.

\begin{tabular}{cccccc}
\hline S.NO & Hypothesis & B & $\boldsymbol{t}$-Value & $\boldsymbol{p}$-Value & Decision \\
\hline H1 & $\mathrm{SL} \rightarrow \mathrm{BV}$ & 0.342 & 6.197 & 0.000 & Supported \\
H2 & $\mathrm{BV} \rightarrow \mathrm{EP}$ & 0.212 & 3.993 & 0.000 & Supported \\
$\mathrm{H} 3$ & $\mathrm{SL} \rightarrow \mathrm{SE}$ & 0.418 & 7.528 & 0.010 & Supported \\
$\mathrm{H} 4$ & $\mathrm{SE} \rightarrow \mathrm{EP}$ & 0.436 & 7.160 & 0.000 & Supported \\
$\mathrm{H} 5$ & $\mathrm{SE} \rightarrow \mathrm{BV}$ & 0.381 & 6.367 & 0.000 & Supported \\
\hline
\end{tabular}




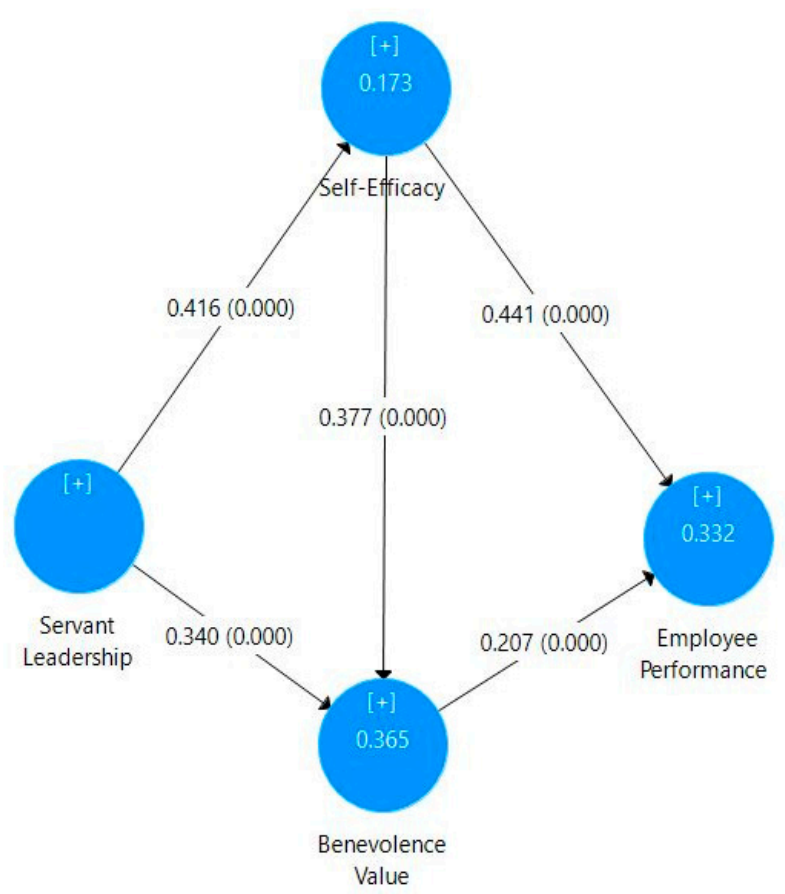

Figure 4. Structural model path coefficient and $p$ values.

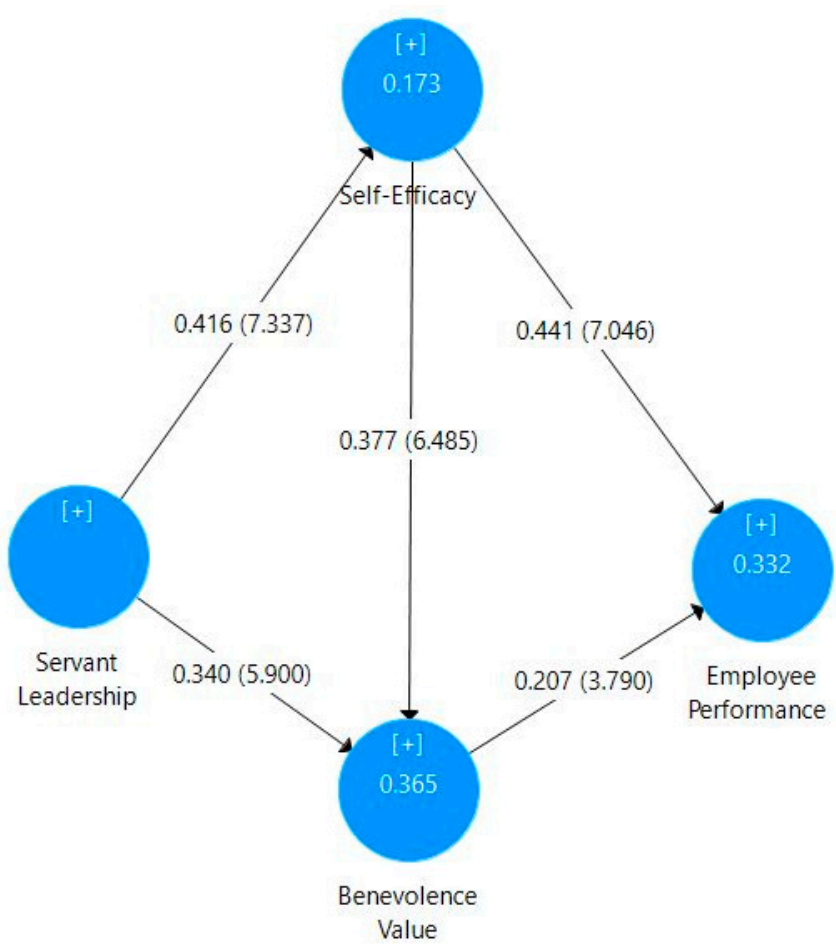

Figure 5. Structural model path coefficient and T values.

This study examined mediating relationships and proposed five hypotheses, e.g., (i) $\mathrm{H6}: \mathrm{SL} \rightarrow \mathrm{BV} \rightarrow \mathrm{EP}$, (ii) H7: SL- $\rightarrow \mathrm{SE} \rightarrow \mathrm{EP}$ (iii) $\mathrm{H} 8: \mathrm{SE}-\rightarrow \mathrm{BV} \rightarrow \mathrm{EP}$ (iv) H9: SL $\rightarrow \mathrm{SE} \rightarrow \mathrm{BV}$ (v) H10: SL- $\rightarrow$ SE $\rightarrow$ BV $\rightarrow$ EP. See Figures 4 and 5 for path coefficient $(\beta)$, p-values, and t-values.

Table 7 summarizes the results of mediating hypotheses, e.g., H6 to H10 by taking into consideration the three statistics such as (i) path coefficient (ii) ( $\beta$ ), p-values, and (iii) tvalues. To assess the strength of mediation or type (a) full, (b) partial, and (c) no mediation, the variance account for (VAF) value was calculated. The VAF $>80 \%$ represent full type, VAF $<80 \%$ shows partial mediation, while VAF $<20 \%$ expects there is no mediation. 
According to the result, all mediating hypotheses, e.g., (H6 to H10) were supported. Moreover, full mediation was observed in the case of H6, H8 and H10, while partial mediation was observed in the case of hypotheses $\mathrm{H} 7$ and $\mathrm{H} 9$.

Table 7. Hypothesis testing (Test of Indirect Effects/Mediation).

\begin{tabular}{|c|c|c|c|c|c|c|c|}
\hline \multicolumn{2}{|c|}{ S.NO } & \multirow{2}{*}{$\begin{array}{l}\text { Hypothesis } \\
\mathrm{SL} \rightarrow \mathrm{BV} \rightarrow \mathrm{EP}\end{array}$} & \multirow{2}{*}{$\frac{\text { Indirect } \beta}{0.073}$} & \multirow{2}{*}{$\frac{t \text {-Value }}{3.359}$} & \multirow{2}{*}{$\frac{p \text {-Value }}{0.001}$} & \multirow{2}{*}{$\begin{array}{l}\text { Mediation Type Assessed Via VAF } \\
\text { VAF }=81 \% \text { Full mediation }\end{array}$} & \multirow{2}{*}{$\begin{array}{l}\text { Decision } \\
\text { Supported }\end{array}$} \\
\hline H6 & M1 & & & & & & \\
\hline H7 & M2 & $\mathrm{SL}-\rightarrow \mathrm{SE} \rightarrow \mathrm{EP}$ & 0.183 & 4.656 & 0.000 & VAF $=63 \%$ Partial mediation & Supported \\
\hline H8 & M3 & $\mathrm{SE}-\rightarrow \mathrm{BV} \rightarrow \mathrm{EP}$ & 0.082 & 2.982 & 0.003 & VAF $=84 \%$ Full mediation & Supported \\
\hline H9 & M4 & $\mathrm{SL}-\rightarrow \mathrm{SE} \rightarrow \mathrm{BV}$ & 0.159 & 5.145 & 0.000 & VAF $=68 \%$ Partial mediation & Supported \\
\hline H10 & M5 & $\mathrm{SL}-\rightarrow \mathrm{SE} \rightarrow \mathrm{BV} \rightarrow \mathrm{EP}$ & 0.034 & 2.853 & 0.001 & VAF $=90 \%$ Full mediation & Supported \\
\hline
\end{tabular}

\subsection{The Explanatory Power of the Model (R2), Predictive Relevance Q2, and Effect Size (q2)}

The R2 explains the endogenous factors (BV, SE, and $\mathrm{EP}$ ) reflecting how much the exogenous variable SL predict the endogenous factors. The $\mathrm{R}^{2}$ value ranges in between $0<\mathrm{r}^{2}<1$, demonstrating more significant levels of prescient exactness (Hair et al. 2014). The $\mathrm{R}^{2}$ value for the EP was 0.335, implying that BV, SL, and SE explain EP around 33\%.

Notwithstanding $R^{2}$, another rule proposed by Stone-Geisser's $Q^{2}$ is additionally utilized for predictive relevance (Geisser 1974; Stone 1974). The $\mathrm{Q}^{2}$ is determined by using the blindfolding procedure. It is an example reuse method where information focuses are discarded and re-assessed. In this way, $\mathrm{Q}^{2}$ shows how well the information gathered experimentally can be rebuilt with model and PLS paraments (Akter et al. 2011). $Q^{2}$ esteem more noteworthy than zero for a particular intelligent endogenous inert variable demonstrates the way model's prescient significance for a reliant variable. As displayed in Table $8, \mathrm{Q}^{2}$ for BV was 0.210 , EP 0.184 , and SE 0.211 , showing a satisfactory degree of predictive relevance. In general, the model has good $Q^{2}$, which further affirms the predictive relevance of the structural model.

Table 8. $R^{2}$, predictive relevance $Q^{2}$.

\begin{tabular}{ccccc}
\hline Endogenous Variable & $\mathbf{R}^{\mathbf{2}}$ Values & Threshold & $\mathbf{Q}^{\mathbf{2}}$ Values & Threshold \\
\hline BV & 0.374 & $\geq 0.33$ (moderate) & 0.210 & $>0$ \\
EP & 0.335 & $\geq 0.33$ (moderate) & 0.184 & $>0$ \\
SE & 0.379 & $\geq 0.33$ (moderate) & 0.211 & $>0$ \\
\hline
\end{tabular}

The $\mathrm{Q}^{2}$ esteem shows models' predictive relevance of the way model. Nonetheless, it does not show the general effect of predictive relevance. To set up relative significance, $\mathrm{q}^{2}$ impact size is determined: $\mathrm{q}_{2}=\left(\mathrm{Q}^{2}\right.$ included $-\mathrm{Q}^{2}$ excluded $) /\left(1-\mathrm{Q}^{2}\right.$ included $)$. For example, $\mathrm{SL} \mathrm{q}^{2}=(0.184-0.249) /(1-0.184)=\mathrm{q}^{2}$ impact size . These estimations of $\mathrm{q}^{2}$ were rehashed for all developments, as displayed in Table 8.

\subsection{The PLS-SEM Importance-Performance Matrix Analysis (IPMA)}

The important performance map analysis (IPMA) extends the usual PLS-SEM results by considering average values of the latent scores. In this research, the IPMA was conducted for employee performance as a particular endogenous variable alongside exogenous constructs, e.g., benevolence values, self-efficacy, servant leadership on the x-axis, and employee performance on the $y$-axis (Hair et al. 2014). Table 9 exhibits the latent variables index values in the inner model and the exogenous latent variables' total effects (indicating direct effects in this specific case) on the endogenous latent variable "employee performance." Figure 6 delineates the IPMA guide of employee performance. The significant IPMA analysis showed that all critical factors, such as benevolence values, servant leadership, and self-efficacy, are substantial in determining employee performance. Self-efficacy has the most noteworthy worth, for example, 72.198 among all. 
Table 9. IMPA results.

\begin{tabular}{ccc}
\hline Latent Variables & EP Total Effect Performance & Index Value Performance \\
\hline BV & 0.176 & 71.340 \\
SE & 0.490 & 72.198 \\
EP & 0.230 & 68.764 \\
\hline
\end{tabular}

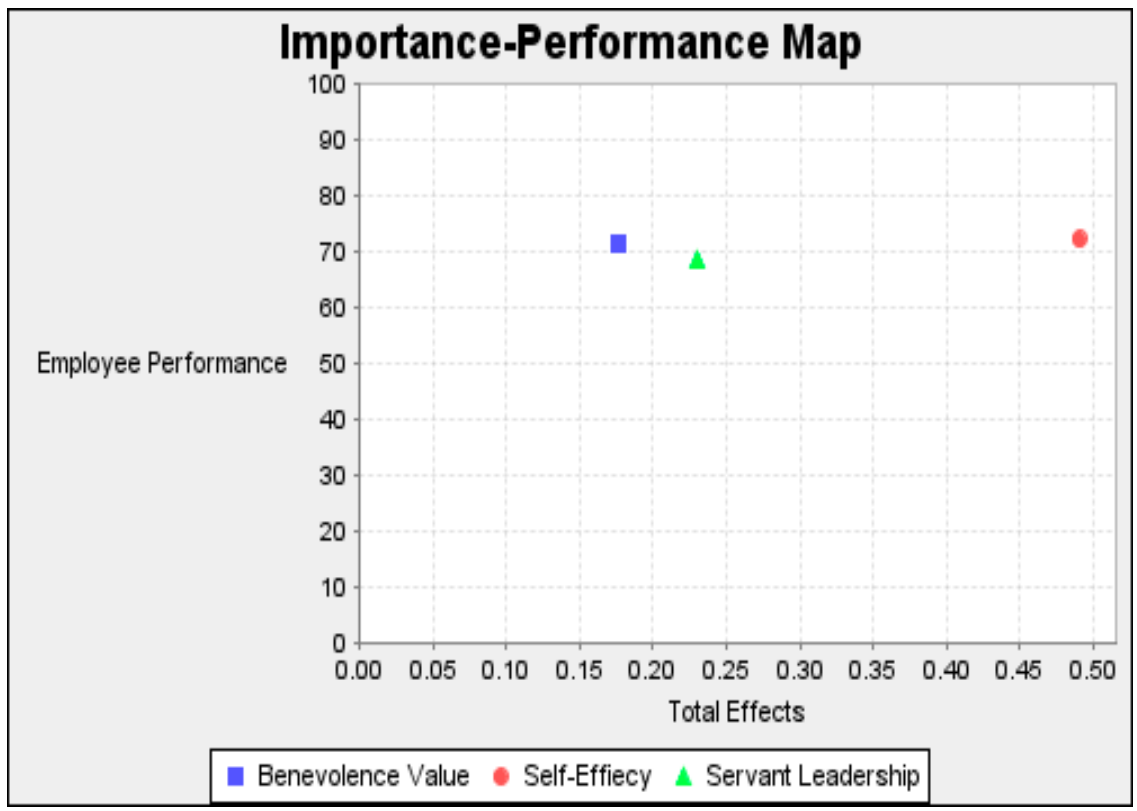

Figure 6. PLS-SEM importance-performance matrix analysis (IPMA).

\section{Research Findings and Discussion}

Current study investigates the mediating role SE and BV on the relationship between SL and EP. This research aims to investigate enhance our understanding about the impact of servant leadership on employee performance through mediating role of benevolence values and self-efficacy. To begin with, we have found significant supportive evidence for justifying our hypothesized relationships among SL and EP via indirect effects of BV and SE among employees of banking sector.

The structural equation model technique (SEM) was employed to check the mediating role of benevolence values and employee self-efficacy on the relationship between SL and EP. Our research study was based on three major objectives first, to test the indirect effect of self-efficacy on the relationship between servant leadership and employee performance. The results have confirmed that self-efficacy partially mediate the relationship between the servant leadership and employee. These results are aligned with the previous research findings that established a positive relationship between servant leadership and self-efficacy. Moreover, a significant relationship exists between employee self-efficacy and its impact on performance (Almahdali et al. 2021; Harwiki 2016; Pratiwi and Nawangsari 2021; Zeeshan et al. 2021). The second objective was to test the indirect effect of benevolence values on the relationship between servant leadership and employee performance. Benevolence values fully mediate the relationship between SL and EP. Morrison (2018) has concluded that values of leadership, especially benevolences, impact the leadership style. Building on this further confirmed that benevolence values mediate this relationship and positively impact the performance. Third objective was to test the serial mediation of self-efficacy and benevolence values on the relationship between servant leadership and employee performance. The result confirmed both SE and BV serially mediate the relationship between SL and EP. The variance accounted for (VAF) value shows $90 \%$ establishing full serial mediation. According to Barbuto and Wheeler (2006), servant leaders can improve 
employee performance, such as the additional work made by employees, and increase organizational effectiveness. Leaders should perceive the positive consequences of their leadership in engaging and fostering their individuals to give work fulfillment, eventually adding to the employee involvement and working on their performance.

Servant leadership has no immediate impact on task performance, adaptive performance as at first model consisted of these factors, although it directly affects the contextual performance. These findings are significant since they affirm the principal reason of servant leadership on values of employees and leaders, especially the relevant mediation role of benevolence values. Our research responds to the previous call, that was given to investigate the mediating effect of these values on the relationship between servant leadership and' performance (Chiniara and Bentein 2018). Our work additionally expands the understanding of the impact of SL on EP using SE and BV as mediators at the individual level. It explains the indirect effects of how benevolence values and self-efficacy intervenes between these relationships. Our findings are aligned with the previous research results that self-efficacy positively impacting leadership and performance. Likewise, Ji and Yoon (2021) have also highlighted self-efficacy as an integral component in explaining servant leadership.

There is an aberrant effect of servant leadership on employee performance. Chiniara and Bentein (2016) have concluded that "servant leaders tend to build trustworthy dyadic relationships with followers and create a psychologically safe and fair climate where employees strongly feel they can be themselves, make their own decisions, and feel connected to others, which naturally leads to the adoption of helpful behaviors towards colleagues and conscientious behaviors in favor of the organization" (p. 136). Mediation test results also establish how both benevolence values and self-efficacy build and both mediate and positively impact the relationship of servant leadership and employee performance. In keeping with the conceptual attributes of servant leadership, these results suggest that benevolence values and self-efficacy, established through mutual exchange of concern and care between the subordinate and leader, are translated into positive work outcomes.

\section{Research Implications, Limitations, and Future Directions}

This research brings important theoretical and practical implications for employees' financial industry experts and behavioral researchers. Employees have open conversations regarding serving and being a worker. Servant leaders do not need to be officially designated. Employees at any position and in any situation can go for servant leader behavior. Research findings conclude that values and beliefs both act as significant predecessors of performance. At a practical level, it would be beneficial for leaders to train colleagues on the most proficient method to take part in leadership practices to increase performance. The managerial implication of this study brings relevant implications for the HR administration and the overall management that these findings can be utilized to acquire a comprehensive insight into employee performance. Employee performance is exceptionally dependent upon leadership style. Worker performance is highly subject to the upsides of leaders alongside the employee belief. The findings of this research can significantly contribute to the banking sector and enable them to improve their employee's performance. Leaders and managers should not only provide work orders and should facilitate workers who genuinely need help to focus on their tasks. Likewise, in connection to this, employees should also attempt to practice their leaders' values and reciprocally offer help and support to each other to improve their work performance genuinely.

This study also brings some limitations. This research has employed primary data that is cross-sectional in nature. The employees of private banks participated in this research. However, the result of this study is only applicable to the banking industry. Current research findings cannot be generalized to other sectors. This study uses relatively a small sample, e.g., (400), for analysis; keeping this in mind, future studies should employ longitudinal and multi-wave data using bigger sample to enhance generalizability of results (Sekaran and Roger 2016). 
We also strongly recommend that future studies should consider other antecedents in the model that predict employee performance by using demographic variables as moderators. Literature provides evidence for team performance (Tekleab et al. 2016). To extend the debate on performance, we suggest researchers should assess team performance in the future. Lastly, servant leadership theory talks about the influence of leaders on their surroundings (Greenleaf 1991). Our findings revealed how we could make serving society. We assumed that this phenomenon happens through a leader's model, yet we could not empirically test it. Future research might adopt an organizational approach to assess the genuine impact of servant leaders on their employees in a different corporate setting.

Author Contributions: Conceptualization, T.M. and N.U.K.; methodology, G.Y.; software, H.A.B.; validation, N.U.K.; formal analysis, T.M.; investigation, N.U.K.; resources, H.A.B.; data curation, N.U.K.; writing—original draft preparation, T.M.; writing—review and editing, A.O.; G.Y. and N.A.S. All authors have read and agreed to the published version of the manuscript.

Funding: This research received no external funding.

Institutional Review Board Statement: Not applicable.

Informed Consent Statement: Not applicable.

Data Availability Statement: The data presented in this study are available on request from the corresponding author.

Conflicts of Interest: The authors declare no conflict of interest.

\section{Appendix A}

\section{Appendix A.1. Survey Measures}

The key constructs of this study, e.g., BV, SL, SE and EP, were measured with a five-point Likert scale (strongly disagree $=1$, disagree $=2$, neutral $=3$, agree $=4$, strongly agree $=5$ ) .

\section{Benevolence value}

BV1 It is important to him to be loyal to those who are close to him.

BV2 He goes out of his way to be a dependable and trustworthy friend.

BV3 He wants those he spends time with to be able to rely on him completely.

BV4 It's very important to him to help the people dear to him.

BV5 Caring for the well-being of people he is close to is important to him.

BV6 He tries always to be responsive to the needs of his family and friends.

\section{Servant leadership}

SL1 My leader can tell if something work-related is going wrong.

SL2 My leader makes my career development a priority

SL3 I would seek help from my leader if I had a personal problem.

SL4 My leader emphasizes the importance of giving back to the community.

SL5 My leader puts my best interests ahead of his/her own.

SL6 My leader gives me the freedom to handle difficult situations in the way that I feel is best.

SL7 My leader would NOT compromise ethical principles in order to achieve success.

\section{Self-efficacy}

SE1 In my work I am confident I can Solve all the conflicts that may occur with my colleagues.

SE2 In my work I am confident I can Keep in a good mood, even in tense situations.

SE3 In my work I am confident I can Defend my rights when treated unfairly.

SE4 In my work I am confident I can Earn the esteem of all my colleagues.

SE5 In my work I am confident I can Remain calm in very stressful situations.

SE6 In my work I am confident I can Overcome all frustrations related to my failures.

SE7 In my work I am confident I can Recover quickly after a period of intense activity. 


\section{Employee performance}

EP1 CP5 I used to extend help to my co-workers when asked or needed.

EP2 CP1 I love to handle extra responsibilities.

EP3 CP8 I extend my sympathy and empathy to my co-workers when they are in trouble.

EP4 CP4 I actively participate in group discussions and work meetings.

EP5 CP7 I use to praise my co-workers for their good work.

EP6 CP2 I derive lot of satisfaction nurturing others in organization.

EP7 CP3 I use to share knowledge and ideas among my team members.

EP8 CP6 I use to maintain good coordination among fellow workers.

EP9 CP11 I communicate effectively with my colleagues for problem solving and decision making.

EP10 CP10 I use to guide new colleagues beyond my job purview.

EP11 TP9 I use to maintain high standard of work.

EP12 TP14 I am capable of handling my assignments without much supervision.

EP13 TP11 I am very passionate about my work.

EP14 TP10 I know I can handle multiple assignments for achieving organizational goals.

EP15 TP8 I use to complete my assignments on time.

EP16 TP12 My colleagues believe I am a high performer in my organization

EP17 AP11 I use to perform well to mobilize collective intelligence for effective team work. EP18 AP3 I could manage change in my job very well whenever the situation demands.

EP19 AP9 I can handle effectively my work team in the face of change.

EP20 AP6 I always believe that mutual understanding can lead to a viable solution in organization.

EP21 AP8 I use to lose my temper when faced with criticism from my team members. (R) EP22 AP2 I am very comfortable with job flexibility.

EP23 AP12 I use to cope well with organizational changes from time to time.

Appendix A.2.

Table A1. Demographic information.

\begin{tabular}{|c|c|c|}
\hline Demographic Characteristics & Frequency & Percentage \\
\hline \multicolumn{3}{|c|}{ Age } \\
\hline $15-20$ years & 01 & 0.3 \\
\hline $21-30$ years & 214 & 53.5 \\
\hline $31-40$ years & 155 & 38.8 \\
\hline $41-50$ years & 28 & 7 \\
\hline $51+$ years & 02 & 0.5 \\
\hline Total & 400 & 100 \\
\hline \multicolumn{3}{|c|}{ Gender } \\
\hline Male & 251 & 62.7 \\
\hline Female & 149 & 37.3 \\
\hline Total & 400 & 100 \\
\hline \multicolumn{3}{|c|}{ Marital status } \\
\hline Single & 158 & 39.5 \\
\hline Married & 241 & 60.3 \\
\hline Other & 01 & 0.3 \\
\hline Total & 400 & 100 \\
\hline \multicolumn{3}{|c|}{ Education } \\
\hline Bachelors (14 years) & 90 & 22.5 \\
\hline Bachelors/Masters (16 years) & 194 & 48.5 \\
\hline Masters (18 years) & 113 & 28.2 \\
\hline PHD (18+ years) & 03 & 0.8 \\
\hline Total & 400 & 100 \\
\hline
\end{tabular}


Table A1. Cont.

\begin{tabular}{|c|c|c|}
\hline Demographic Characteristics & Frequency & Percentage \\
\hline \multicolumn{3}{|c|}{ Overall Working Experience } \\
\hline 1-10 years & 177 & 44.3 \\
\hline $11-20$ years & 131 & 32.8 \\
\hline $21-30$ years & 54 & 13.5 \\
\hline $31-40$ years & 38 & 9.5 \\
\hline Total & 400 & 100 \\
\hline \multicolumn{3}{|c|}{ Current Employed Years } \\
\hline 1-10 years & 206 & 51.5 \\
\hline $11-20$ years & 102 & 25.5 \\
\hline $21-30$ years & 54 & 13.5 \\
\hline $31-40$ years & 38 & 9.5 \\
\hline Total & 400 & 100 \\
\hline \multicolumn{3}{|c|}{ Organization } \\
\hline Summit Bank Limited & 03 & 0.8 \\
\hline Al Baraka Bank & 07 & 1.8 \\
\hline Allied Bank & 51 & 12.8 \\
\hline Askari Bank & 40 & 10 \\
\hline Bank Al Habib & 09 & 2.3 \\
\hline Bank Alfalah & 71 & 17.8 \\
\hline Bank of Punjab & 12 & 03 \\
\hline Faysal Bank & 34 & 8.5 \\
\hline Habib Bank Limited & 36 & 09 \\
\hline Habib Metro Bank & 10 & 2.5 \\
\hline JSBL & 13 & 3.3 \\
\hline Meezan bank & 13 & 3.3 \\
\hline Muslim Commercial Bank & 43 & 10.8 \\
\hline Samba Bank & 10 & 2.5 \\
\hline Soneri bank & 03 & 0.8 \\
\hline United Bank Limited & 45 & 11.3 \\
\hline Total & 400 & 100 \\
\hline \multicolumn{3}{|c|}{ Position } \\
\hline Teller & 01 & 0.3 \\
\hline Assistant Manager & 10 & 2.5 \\
\hline Banking Officer & 03 & 0.8 \\
\hline Banking services & 02 & 0.5 \\
\hline Banking Services Corporation & 05 & 1.3 \\
\hline Branch Coordinator & 02 & 0.5 \\
\hline Branch Service Manager & 01 & 0.3 \\
\hline Branch Service Officers & 25 & 6.3 \\
\hline Branch services & 01 & 0.3 \\
\hline Branch Services Manager & 01 & 0.3 \\
\hline Branch Services Officers & 01 & 0.3 \\
\hline Business Development Officer & 18 & 4.5 \\
\hline Business Strategy Spread & 01 & 0.3 \\
\hline Business development & 01 & 0.3 \\
\hline center services manager & 01 & 0.3 \\
\hline Credit Manager & 03 & 0.8 \\
\hline Cluster Manager & 03 & 0.8 \\
\hline Compliance Officer & 02 & 0.5 \\
\hline Corporate Social Responsibility & 09 & 02 \\
\hline Credit officer & 03 & 0.8 \\
\hline Customer Service Manage & 09 & 2.3 \\
\hline Customer Service Manager & 04 & 01 \\
\hline Customer Service Officer & 28 & 07 \\
\hline
\end{tabular}


Table A1. Cont.

\begin{tabular}{|c|c|c|}
\hline Demographic Characteristics & Frequency & Percentage \\
\hline Development officer & 05 & 1.3 \\
\hline Foreclosure charges & 02 & 0.5 \\
\hline General Banking Officer & 18 & 4.5 \\
\hline In charge & 01 & 0.3 \\
\hline In charge Banking & 05 & 1.3 \\
\hline Insurance Consultant & 06 & 1.5 \\
\hline IT Officer & 23 & 5.8 \\
\hline Locker Custodian & 01 & 0.3 \\
\hline Operation & 05 & 1.3 \\
\hline Operation Manager & 10 & 2.5 \\
\hline Operation Officer & 07 & 1.8 \\
\hline Operations & 02 & 0.5 \\
\hline Personal Banker Officer & 04 & 01 \\
\hline Personal Banking Officer & 09 & 2.3 \\
\hline Processing Officer & 01 & 0.3 \\
\hline Regional sales manager & 01 & 0.3 \\
\hline Relationship Manager & 45 & 11.3 \\
\hline Relationship Officer & 14 & 3.5 \\
\hline Retail Officers & 01 & 0.3 \\
\hline Revenue Expenditure & 02 & 0.5 \\
\hline Reverse Takeover & 03 & 0.8 \\
\hline Sales Officer & 04 & 01 \\
\hline Senior teller & 01 & 0.3 \\
\hline Service Ambassador & 03 & 0.8 \\
\hline Services Officer & 12 & 03 \\
\hline Services Supervisor & 01 & 0.3 \\
\hline Team Manager & 05 & 1.3 \\
\hline Tele Operator & 01 & 0.3 \\
\hline Teller & 64 & 16 \\
\hline Teller Services Officer & 06 & 1.5 \\
\hline Trade Officer & 04 & 01 \\
\hline Total & 400 & 100 \\
\hline
\end{tabular}

\section{References}

Abbas, Ansar, Muhammad Saud, Indrianawati Usman, and Dian Ekowati. 2020. Servant leadership and religiosity: An indicator of employee performance in the education sector. International Journal of Innovation, Creativity Change 13: 391-409.

Aguilar, Tony, and Jessica Yuan. 2010. Measuring restaurant managers' self-efficacy and job satisfaction with generational position. Paper presented at the 15th Annual Graduate Student Research Conference in Hospitality and Tourism, Washington, DC, USA, January 7-9.

Akter, Shahriar, John D'ambra, and Pradeep Ray. 2011. An Evaluation of PLS Based Complex Models: The Roles of Power Analysis, Predictive Relevance and GoF Index. Available online: https:/ / ro.uow.edu.au/commpapers/3126/ (accessed on 21 March 2021).

Ali, Faizan, S. Mostafa Rasoolimanesh, Marko Sarstedt, Christian M. Ringle, and Kisang Ryu. 2018. An assessment of the use of partial least squares structural equation modeling (PLS-SEM) in hospitality research. International Journal of Contemporary Hospitality Management 30: 514-38. [CrossRef]

Ali, Hafiz Yasir, Muhammad Asrar-ul-Haq, Shaheera Amin, Sadaf Noor, Muhammad Haris-ul-Mahasbi, and Muhammad Kashif Aslam. 2020. Corporate social responsibility and employee performance: The mediating role of employee engagement in the manufacturing sector of Pakistan. Corporate Social Responsibility Environmental Management 27: 2908-19. [CrossRef]

Ali, Majid, Hafiz Abdur Rashid, Muhammad Hasnain Ali, Muhammad Usman, and Aamir Sohail. 2021. Assessment of Customers E-loyalty in digital banking During COVID-19: An application of 8C model. International Journal of Disaster Recovery and Business Continuity 12: 1054-62.

Almahdali, Fadila, Syahir Natsir, Bakri Hasanuddin, and Husnah Husnah. 2021. The Effect of Servant Leadership, Emotional Intelligence, and Self-Efficacy on Organizational Citizenship Behavior and Employee Performance of State-Owned Banks in Palu City. International Journal of Multicultural Multireligious Understanding 8: 682-94.

Almeida, Fernando, and José Duarte Santos. 2020. The effects of COVID-19 on job security and unemployment in Portugal. International Journal of Sociology Social Policy 40: 995-1003. [CrossRef]

Baard, Samantha K., Tara A. Rench, and Steve W. J. Kozlowski. 2014. Performance adaptation: A theoretical integration and review. Journal of Management 40: 48-99. [CrossRef] 
Babakus, Emin, Ugur Yavas, Osman M. Karatepe, and Turgay Avci. 2003. The effect of management commitment to service quality on employees' affective and performance outcomes. Journal of the Academy of Marketing Science 31: 272-86. [CrossRef]

Bandura, Albert. 1977. Self-efficacy: Toward a unifying theory of behavioral change. Psychological Review 84: 191. [CrossRef] [PubMed]

Bandura, Albert. 1986. Social Foundations of Thought and Action. Englewood Cliffs: Prentice-Hall, pp. 23-28.

Bandura, Albert. 1997. The anatomy of stages of change. American Journal of Health Promotion: AJHP 12: 8-10. [CrossRef] [PubMed]

Bandura, Albert. 2006. Guide for constructing self-efficacy scales. Self-Efficacy Beliefs of Adolescents 5: 307-37.

Bandura, Albert. 2012. On the Functional Properties of Perceived Self-Efficacy Revisited. Los Angeles: Sage Publications Sage CA.

Bandura, Albert, and Richard H. Walters. 1977. Social Learning Theory. Englewood Cliffs: Prentice-Hall, vol. 1.

Bandura, Albert, Nancy E. Adams, and Janice Beyer. 1977. Cognitive processes mediating behavioral change. Journal of Personality Social Psychology 35: 125. [CrossRef]

Barbuto, John E., Jr., and Daniel W. Wheeler. 2006. Scale development and construct clarification of servant leadership. Group Organization Management 31: 300-26. [CrossRef]

Bardi, Anat, and Shalom H. Schwartz. 2003. Values and behavior: Strength and structure of relations. Personality and Social Psychology Bulletin 29: 1207-20. [CrossRef]

Barni, Daniela, Francesca Danioni, and Paula Benevene. 2019. Teachers' self-efficacy: The role of personal values and motivations for teaching. Frontiers in Psychology 10: 1645. [CrossRef] [PubMed]

Bass, Bernard M. 1985. Leadership and Performance beyond Expectations. New York: Collier Macmillan.

Baum, Tom, Shelagh K. K. Mooney, Richard N. S. Robinson, and David Solnet. 2020. COVID-19's impact on the hospitality workforcenew crisis or amplification of the norm? International Journal of Contemporary Hospitality Management 32: 2813-19. [CrossRef]

Bono, Joyce E., and Timothy A. Judge. 2003. Self-concordance at work: Toward understanding the motivational effects of transformational leaders. Academy of Management Journal 46: 554-71.

Borgogni, Laura, Silvia Dello Russo, Laura Petitta, and Michele Vecchione. 2010. Predicting job satisfaction and job performance in a privatized organization. International Public Management Journal 13: 275-96. [CrossRef]

Borman, Walter C., and S. M. Motowidlo. 1993. Expanding the criterion domain to include elements of contextual performance. Psychology Faculty Publications, 1111. Available online: https://digitalcommons.usf.edu/psy_facpub/1111 (accessed on 13 April 2021).

Brief, Arthur P., and Stephan J. Motowidlo. 1986. Prosocial organizational behaviors. Academy of Management Review 11: 710-25. [CrossRef]

Budhwar, Pawan S., and Anil Chandrakumara. 2007. Does HRM fit really matter to citizenship and task performance? Employee Relations 29: 611-39.

Buil, Isabel, Eva Martínez, and Jorge Matute. 2019. Transformational leadership and employee performance: The role of identification, engagement and proactive personality. International Journal of Hospitality Management 77: 64-75. [CrossRef]

Campbell, John P. 1990. Modeling the performance prediction problem in industrial and organizational psychology. Handbook of Industrial and Organizational Psychology; Edited by M. D. Dunnette and L. M. Hough. Palo Alto: Consulting Psychologists Press, pp. 687-732. Available online: https://psycnet.apa.org/record/1993-97198-012 (accessed on 10 February 2021).

Cannavale, Chiara, Iman Zohoorian Nadali, and Anna Esempio. 2020. Entrepreneurial orientation and firm performance in a sanctioned economy-Does the CEO play a role? Journal of Small Business Enterprise Development 27: 1005-27. [CrossRef]

Caprara, Gian Vittorio, and Patrizia Steca. 2007. Prosocial agency: The contribution of values and self-efficacy beliefs to prosocial behavior across ages. Journal of Social Clinical Psychology 26: 218-39. [CrossRef]

Carter, W. Richard, Paul L. Nesbit, Richard J. Badham, Sharon K. Parker, and Li-Kuo Sung. 2018. The effects of employee engagement and self-efficacy on job performance: A longitudinal field study. The International Journal of Human Resource Management 29: 2483-502. [CrossRef]

Chan, Simon C. H., and Wai-ming Mak. 2014. The impact of servant leadership and subordinates' organizational tenure on trust in leader and attitudes. Personnel Review 43: 272-87. [CrossRef]

Charalambous, George, Nikolaos Xenikakis, Alexandra Skitsou, Elpiniki Biskanaki, and Olympia Konstantakopoulou. 2018. Job Satisfaction of Mental Health Workers in Psychïsocial Rehabilitation Centres in a Rural Area of Greece. International Journal of Caring Sciences 11: 1438-49.

Charbonnier-Voirin, Audrey, and Patrice Roussel. 2012. Adaptive performance: A new scale to measure individual performance in organizations. Canadian Journal of Administrative Sciences/Revue Canadienne des Sciences de l'Administration 29: 280-93. [CrossRef]

Chen, Ziguang, Wing Lam, and Jian An Zhong. 2007. Leader-member exchange and member performance: A new look at individuallevel negative feedback-seeking behavior and team-level empowerment climate. Journal of Applied Psychology 92: 202. [CrossRef]

Chen, Zhijun, Jing Zhu, and Mingiian Zhou. 2015. How does a servant leader fuel the service fire? A multilevel model of servant leadership, individual self identity, group competition climate, and customer service performance. Journal of Applied Psychology 100: 511. [CrossRef]

Chiniara, Myriam, and Kathleen Bentein. 2016. Linking servant leadership to individual performance: Differentiating the mediating role of autonomy, competence and relatedness need satisfaction. The Leadership Quarterly 27: 124-41. [CrossRef]

Chiniara, Myriam, and Kathleen Bentein. 2018. The servant leadership advantage: When perceiving low differentiation in leadermember relationship quality influences team cohesion, team task performance and service OCB. The Leadership Quarterly Bentein 29: 333-45. [CrossRef] 
Chughtai, Aamir Ali. 2016. Servant leadership and follower outcomes: Mediating effects of organizational identification and psychological safety. The Journal of Psychology 150: 866-80. [CrossRef] [PubMed]

Dagar, Chirag, Ashish Pandey, and Ajinkya Navare. 2020. How Yoga-Based Practices Build Altruistic Behavior? Examining the Role of Subjective Vitality, Self-transcendence, and Psychological Capital. Journal of Business Ethics, 1-16. [CrossRef]

De Clercq, Dirk, and Inam Ul Haq. 2018. Self-efficacy to spur job performance: Roles of job-related anxiety and perceived workplace incivility Dirk De Clercq, Inam Ul Haq, Muhammad Umer Azeem. Management Decision 56: 891-907. [CrossRef]

Delmas, Magali A., and Sanja Pekovic. 2018. Organizational configurations for sustainability and employee productivity: A qualitative comparative analysis approach. Business $\mathcal{E}$ Society 57: 216-51.

DeYoung, Matthew. 2020. Examining The Relationship Between Personal Values and Servant Leadership Behavior. Minneapolis: Capella University.

Egri, Carolyn P., and Susan Herman. 2000. Leadership in the North American environmental sector: Values, leadership styles, and contexts of environmental leaders and their organizations. Academy of Management Journal 43: 571-604.

Ekhsan, Muhamad, and Ali Aziz. 2021. Servant Leadership and Employee Performance: Does Organizational Commitment Mediate in the Model? Proceeding The First International Conference on Government Education Management and Tourism 1: 373-82.

Feather, Norman T. 1990. Bridging the gap between values and actions: Recent applications of the expectancy-value model. Handbook of Motivation and Cognition: Foundations of Social Behavior 2: 151-92.

Feather, Norman T. 1995. Values, valences, and choice: The influences of values on the perceived attractiveness and choice of alternatives. Journal of Personality and Social Psychology 68: 1135. [CrossRef]

Felfe, Jörg, and Birgit Schyns. 2006. Personality and the Perception of Transformational Leadership: The Impact of Extraversion, Neuroticism, Personal Need for Structure, and Occupational Self-Efficacy 1. Journal of Applied Social Psychology 36: 708-39. [CrossRef]

Ferdinand, Augusty. 2006. Metode Penelitian Manajemen. Semarang: Badan Penerbit Universitas Diponegoro.

Fu, Ping Ping, Anne S Tsui, Jun Liu, and Lan Li. 2010. Pursuit of whose happiness? Executive leaders' transformational behaviors and personal values. Administrative Science Quarterly 55: 222-54. [CrossRef]

Geisser, Seymour. 1974. A predictive approach to the random effect model. Biometrika 61: 101-107. [CrossRef]

Gong, Yaping, Jia-Chi Huang, and Jiing-Lih Farh. 2009. Employee learning orientation, transformational leadership, and employee creativity: The mediating role of employee creative self-efficacy. Academy of Management Journal 52: 765-78. [CrossRef]

Grant, Adam M. 2008. The significance of task significance: Job performance effects, relational mechanisms, and boundary conditions. Journal of Applied Psychology 93: 108. [CrossRef]

Greenleaf, R. K. 1991. The Servant as Leader (Rev. ed.). Indianapolis: Robert K. Greenleaf Center.

Griffin, Mark A., Andrew Neal, and Sharon K. Parker. 2007. A new model of work role performance: Positive behavior in uncertain and interdependent contexts. Academy of Management Journal 50: 327-47. [CrossRef]

Haider, Aftab, and Hafiz Mushtaq. 2017. Self-Efficacy as a Mediator in the Relationship between Servant Leadership and Teaching Effectiveness. Journal of Managerial Sciences 11: 167-82.

Hair, Joe F., Jr., Marko Sarstedt, Lucas Hopkins, and Volker G. Kuppelwieser. 2014. Partial least squares structural equation modeling (PLS-SEM): An emerging tool in business research. European Business Review 26: 106-21. [CrossRef]

Halawi, Ali, and Nada Haydar. 2018. Effects of Training on Employee Performance: A Case Study of Bonjus and Khatib \& Alami Companies. International Humanities Studies 5: 24-45.

Harwiki, Wiwiek. 2016. The impact of servant leadership on organization culture, organizational commitment, organizational citizenship behaviour (OCB) and employee performance in women cooperatives. Procedia-Social Behavioral Sciences 219: 283-90. [CrossRef]

Hermawati, Adya, and Nasharuddin Mas. 2017. Mediation effect of quality of worklife, job involvement, and organizational citizenship behavior in relationship between transglobal leadership to employee performance. International Journal of Law Management 59: 1143-58. [CrossRef]

Hidayat, Tedi, Rahmi Fahmy, Dessy Kurnia Sari, Fineke Mergeresa, and Yudi Fernando. 2021. COVID-19 outbreak effects on leadership, job satisfaction and turnover intention: A mediating model of Indonesian banking sector. International Journal of Law Management 10: 113-28.

Hoch, Julia E., William H. Bommer, James H. Dulebohn, and Dongyuan Wu. 2018. Do ethical, authentic, and servant leadership explain variance above and beyond transformational leadership? A meta-analysis. Journal of Management 44: 501-29. [CrossRef]

Hunter, Emily M., Mitchell J. Neubert, Sara Jansen Perry, L. A. Witt, Lisa M. Penney, and Evan Weinberger. 2013. Servant leaders inspire servant followers: Antecedents and outcomes for employees and the organization. The Leadership Quarterly $24: 316-31$. [CrossRef]

Iqbal, N., S. Anwar, and N. Haider. 2015. Effect of leadership style on employee performance. Arabian Journal of Business Management Review 5: 1-6.

Ji, Yunho, and Hyun Joong Yoon. 2021. The Effect of Servant Leadership on Self-Efficacy and Innovative Behaviour: Verification of the Moderated Mediating Effect of Vocational Calling. Administrative Sciences 11: 39. [CrossRef]

Jiang, Jane Yan, Anne S. Tsui, and Jia Li. 2015. Servant leadership, changes in personal values, and job meaningfulness. In Academy of Management Proceedings. Briarcliff Manor: Academy of Management. 
Johnson, Jeff W. 2001. The relative importance of task and contextual performance dimensions to supervisor judgments of overall performance. Journal of Applied Psychology 86: 984. [CrossRef]

Judge, Timothy A., and Ronald F. Piccolo. 2004. Transformational and transactional leadership: A meta-analytic test of their relative validity. Journal of Applied Psychology 89: 755. [CrossRef] [PubMed]

Jundt, Dustin K., Mindy K. Shoss, and Jason L. Huang. 2015. Individual adaptive performance in organizations: A review. Journal of Organizational Behavior 36: S53-S71. [CrossRef]

Kaushik, Arun Kumar, and Zillur Rahman. 2015. Innovation adoption across self-service banking technologies in India. International Journal of Bank Marketing 33: 96-121. [CrossRef]

Khushk, Amir Ali, and Peace Works. 2019. Impact of Locus of Control (LOC) and Organizational Commitment on Employee Performance-Study of Service Sector, Pakistan. International Journal of Law 6: 1-6.

Kim, Mi Jin, and Jin H. Park. 2020. Academic Self-Efficacy and Life Satisfaction Among Adolescents: Mediating Effects of SelfTranscendence. Child \& Youth Services 41: 387-408.

Kline, Rex B. 2011. Convergence of structural equation modeling and multilevel modeling. In The SAGE Handbook of Innovation in Social Research Methods. London: SAGE Publications Ltd, pp. 562-89.

Kumar Behera, Ajay, Narayan Chandra Nayak, Harish Chandra Das, and Rabindra Narayan Mohapatra. 2015. An empirical study of the impact of IT on performance in Indian service industries. Global Business Organizational Excellence 34: 67-78. [CrossRef]

Kwon, Sang Soon, and Kyung Seok Kang. 2017. A Study on the Perception of Youth about Health Teacher's Servant Leadership, Student's Self-efficacy, and Health Promoting Behavior, and the Relationship among the Variables. Journal of the Korean Society of School Health 30: 224-39.

Lemoine, G. James, and Terry C. Blum. 2021. Servant leadership, leader gender, and team gender role: Testing a female advantage in a cascading model of performance. Personnel Psychology 74: 3-28. [CrossRef]

Leyer, Michael, Ann-Kathrin Hirzel, and Juergen Moormann. 2021. It's mine, i decide what to change: The role of psychological ownership in employees'process innovation behaviour. International Journal of Innovation Management 25: 2150013. [CrossRef]

Liden, Robert C., Sandy J. Wayne, Hao Zhao, and David Henderson. 2008. Servant leadership: Development of a multidimensional measure and multi-level assessment. The Leadership Quarterly 19: 161-77. [CrossRef]

Liden, Robert C., Alexandra Panaccio, Jeremy D. Meuser, Jia Hu, and Sandy J. Wayne. 2014a. Servant leadership: Antecedents, processes, and outcomes. In The Oxford Handbook of Leadership and Organizations. London: Oxford University Press, pp. 357-79. [CrossRef]

Liden, Robert C., Sandy J. Wayne, Chenwei Liao, and Jeremy D. Meuser. 2014b. Servant leadership and serving culture: Influence on individual and unit performance. Academy of Management Journal 57: 1434-52. [CrossRef]

Liden, Robert C., Sandy J. Wayne, Jeremy D. Meuser, Jia Hu, Junfeng Wu, and Chenwei Liao. 2015. Servant leadership: Validation of a short form of the SL-28. The Leadership Quarterly 26: 254-69. [CrossRef]

Mayer, David M., Mary Bardes, and Ronald F. Piccolo. 2008. Do servant-leaders help satisfy follower needs? An organizational justice perspective. European Journal of Work Organizational Psychology 17: 180-97. [CrossRef]

Mikkelsen, Aslaug, and Espen Olsen. 2019. The influence of change-oriented leadership on work performance and job satisfaction in hospitals-the mediating roles of learning demands and job involvement. Leadership in Health Service 32: 37-53. [CrossRef]

Morrison, Mike A. 2018. Increasing the meaningfulness of work with motivational self-transcendence. International Journal of Existential Psychology Psychotherapy 7: 16-27. [CrossRef]

Neubert, Mitchell J., K. Michele Kacmar, Dawn S. Carlson, Lawrence B. Chonko, and James A. Roberts. 2008. Regulatory focus as a mediator of the influence of initiating structure and servant leadership on employee behavior. Journal of Applied Psychology 93: 1220. [CrossRef]

Otto, Kathleen, Hannah V. Geibel, and Emily Kleszewski. 2021. "Perfect Leader, Perfect Leadership?" Linking Leaders' Perfectionism to Monitoring, Transformational, and Servant Leadership Behavior. Frontiers in Psychology 12: 1290. [CrossRef]

Page, M. Beth, Kathy Bishop, and Catherine Etmanski. 2021. Community Belonging and Values-Based Leadership as the Antidote to Bullying and Incivility. Societies 11: 29. [CrossRef]

Pandey, Jatin. 2019. Factors affecting job performance: An integrative review of literature. Management Research Review 42: 263-89. [CrossRef]

Paracha, M. Umer, Adnan Qamar, Anam Mirza, I.-U. Hassan, and H. Waqas. 2012. Impact of leadership style (transformational \& transactional leadership) on employee performance \& mediating role of job satisfaction. Study of private school (educator) in Pakistan. Global Journal of Management Business Research 12: 55-64.

Peng, J. C., Jia-Jing Jien, and Julian Lin. 2016. Antecedents and consequences of psychological contract breach. Journal of Managerial Psychology 31: 1312-26. [CrossRef]

Pham-Thai, Nguyen T., Adela J. McMurray, Nuttawuth Muenjohn, and Michael Muchiri. 2018. Job engagement in higher education. Personnel Review 47: 951-67. [CrossRef]

Piccolo, Ronald F., and Jason A. Colquitt. 2006. Transformational leadership and job behaviors: The mediating role of core job characteristics. Academy of Management Journal 49: 327-40. [CrossRef]

Podsakoff, Philip M., Scott B. MacKenzie, and William H. Bommer. 1996. Transformational leader behaviors and substitutes for leadership as determinants of employee satisfaction, commitment, trust, and organizational citizenship behaviors. Journal of Management 22: 259-98. [CrossRef] 
Ponta, Linda, Gian Carlo Cainarca, and Silvano Cincotti. 2020. Monetary incentives in Italian public administration: A stimulus for employees? An agent-based approach. Complexity 2020: 1-13. [CrossRef]

Pradhan, Rabindra Kumar, and Lalatendu Kesari Jena. 2017. Employee performance at workplace: Conceptual model and empirical validation. Business Perspectives Research 5: 69-85. [CrossRef]

Pratiwi, Lintang Arum, and Lenny Christina Nawangsari. 2021. Organizational Citizenship Behavior while mediating Self-Efficacy, Servant Leadership and Organization Culture on Employee Performance. European Journal of Business Management Research 6: 225-31. [CrossRef]

Ratten, Vanessa. 2008. Technological innovations in the m-commerce industry: A conceptual model of WAP banking intentions. The Journal of High Technology Management Research 18: 111-17. [CrossRef]

Rezaei, Sajad. 2015. Segmenting consumer decision-making styles (CDMS) toward marketing practice: A partial least squares (PLS) path modeling approach. Journal of Retailing Consumer Services 22: 1-15. [CrossRef]

Richard, Orlando C., Ping Wu, and Ken Chadwick. 2009. The impact of entrepreneurial orientation on firm performance: The role of CEO position tenure and industry tenure. The International Journal of Human Resource Management 20: 1078-95. [CrossRef]

Rivkin, Wladislaw, Stefan Diestel, and Klaus-Helmut Schmidt. 2014. The positive relationship between servant leadership and employees' psychological health: A multi-method approach. German Journal of Human Resource Management 28: 52-72. [CrossRef]

Russell, Robert F., and A. Gregory Stone. 2002. A review of servant leadership attributes: Developing a practical model. Leadership Organization Development Journal 23: 145-57. [CrossRef]

Saad, Mohamed M., Hazem R. Gaber, and Ashraf A. Labib. 2021. Investigating the impact of human resource management practices on employee engagement, and the moderating role of strategy implementation in Egypt. SA Journal of Human Resource Management 19: 9. [CrossRef]

Saleh, Isam, Malik Abu Afifa, and Fares Alsufy. 2020. Does Earnings Quality Affect Companies' Performance? New Evidence from the Jordanian Market. The Journal of Asian Finance, Economics and Business 7: 33-43. [CrossRef]

Schwartz, Shalom H. 1994. Are there universal aspects in the structure and contents of human values? Journal of Social Issues 50: 19-45. [CrossRef]

Schwartz, Shalom H. 2012. An overview of the Schwartz theory of basic values. Online Readings in Psychology and Culture 2. [CrossRef]

Schwartz, Shalom. 2013. Value priorities and behavior: Applying. In The Psychology of Values: The Ontario Symposium. Mahwah: Lawrence Erlbauam Associates (LEA) Inc.

Schwartz, Shalom H., and Tammy Rubel-Lifschitz. 2009. Cross-national variation in the size of sex differences in values: Effects of gender equality. Journal of Personality and Social Psychology 97: 171. [CrossRef]

Schyns, Birgit. 2001. The relationship between employees' self-monitoring and occupational self-efficacy and transformational leadership. Current Research in Social Psychology 7: 30-42.

Sekaran, Uma, and Bougie Roger. 2016. Research Methods for Business: A Skill Building Approach. Hoboken: John Wiley \& Sons.

Sendjaya, Sen. 2016. Personal and Organizational Excellence through Servant Leadership. Berlin: Springer.

Setyaningrum, Retno Purwani, and Avinash Pawar. 2020. Quality Work Life and Employee Engagement: Does Servant Leadership Influence Employee Performance? Solid State Technology 63: 5134-41.

Setyaningrum, Retno Purwani, Margono Setiawan, and Surachman Surachman. 2017. Organizational commitments are mediation of relationships Between servant leadership and employee performance. Jurnal Aplikasi Manajement 15: 693-701. [CrossRef]

Shukla, Amit, and Himanshu Rai. 2015. Linking perceived organizational support to organizational trust and commitment: Moderating role of psychological capital. Global Business Review 16: 981-96. [CrossRef]

Sihombing, Sahat, Endang Siti Astuti, Mochammad Al Musadieq, Djamhur Hamied, and Kusdi Rahardjo. 2018. The effect of servant leadership on rewards, organizational culture and its implication for employee's performance. International Journal of LawManagement 60: 505-16. [CrossRef]

Song, In-Sook, and Sang-Jib Kwon. 2017. An analysis of structural relationships among employee training, servant leadership, self-efficacy, transfer behavior of training, and knowledge sharing. Knowledge Management Research 18: 261-86.

Stajkovic, Alexander D., Albert Bandura, Edwin A. Locke, Dongseop Lee, and Kayla Sergent. 2018. Test of three conceptual models of influence of the big five personality traits and self-efficacy on academic performance: A meta-analytic path-analysis. Personality Individual Differences 120: 238-45. [CrossRef]

Stanton, Pauline, and Hana Thi Pham. 2014. Managing employee performance in an emerging economy: Perceptions of Vietnamese managers. Asia Pacific Business Review 20: 269-85. [CrossRef]

Stollberger, Jakob, Mireia Las Heras, Yasin Rofcanin, and Maria José Bosch. 2019. Serving followers and family? A trickle-down model of how servant leadership shapes employee work performance. Journal of Vocational Behavior 112: 158-71. [CrossRef]

Stone, Mervyn. 1974. Cross-validation and multinomial prediction. Biometrika 61: 509-15. [CrossRef]

Stone, A. Gregory, Robert F. Russell, and Kathleen Patterson. 2004. Transformational versus servant leadership: A difference in leader focus. Leadership Organization Development Journal 25: 349-61. [CrossRef]

Sun, Peter, and Sudong Shang. 2019. Personality traits and personal values of servant leaders. Leadership Organization Development Journal 40: 177-92. [CrossRef]

Sun, Hongyi, Pei-Lee Teh, Karis Ho, and Binshan Lin. 2017. Team diversity, learning, and innovation: A mediation model. Journal of Computer Information Systems 57: 22-30. [CrossRef] 
Tajfel, Henri, ed. 1978. Differentiation between Social Groups: Studies in the Social Psychology of Intergroup Relations. New York: Academic Press.

Tam, Carlos, and Tiago Oliveira. 2017. Literature review of mobile banking and individual performance. International Journal of Bank Marketing 35: 1044-67. [CrossRef]

Tekleab, Amanuel G., Ayse Karaca, Narda R. Quigley, and Eric W. K. Tsang. 2016. Re-examining the functional diversity-performance relationship: The roles of behavioral integration, team cohesion, and team learning. Journal of Business Research 69: $3500-3507$. [CrossRef]

Tripathi, Divya, Pushpendra Priyadarshi, Pankaj Kumar, and Sushil Kumar. 2020. Micro-foundations for sustainable development: Leadership and employee performance. International Journal of Organizational Analysis 28: 92-108. [CrossRef]

Ul Hassan, Masood, Sadia Shaukat, Muhammad Shakeel, and Muhammad Imran. 2012. Interrelations between organizational culture, Innovation and employee performance: Evidence from banking sector of Pakistan. Pakistan Journal of Social Sciences 32: 339-55.

Van Dierendonck, Dirk. 2011. Servant leadership: A review and synthesis. Journal of Management 37: 1228-61. [CrossRef]

Van Dierendonck, Dirk, Daan Stam, Pieter Boersma, Ninotchka De Windt, and Jorrit Alkema. 2014. Same difference? Exploring the differential mechanisms linking servant leadership and transformational leadership to follower outcomes. The Leadership Quarterly 25: 544-62. [CrossRef]

Van Scotter, James, Stephan J. Motowidlo, and Thomas C. Cross. 2000. Effects of task performance and contextual performance on systemic rewards. Journal of Applied Psychology 85: 526. [CrossRef]

Vigoda-Gadot, Eran. 2007. Leadership style, organizational politics, and employees' performance: An empirical examination of two competing models. Personnel Review 36: 661-83. [CrossRef]

Walumbwa, Fred O., Chad A. Hartnell, and Adegoke Oke. 2010. Servant leadership, procedural justice climate, service climate, employee attitudes, and organizational citizenship behavior: A cross-level investigation. Journal of Applied Psychology 95 : 517. [CrossRef] [PubMed]

World Health Organisation. 2020. Coronavirus Disease (COVID-19) Outbrake 2020. Available online: https://www.who.int/ emergencies/diseases/novelcoronavirus-2019 (accessed on 20 March 2021).

Xiongying, Niu, and Zenebe Garedew Boku. 2021. Impact of Servant Leadership on Employee Performance in Public Sectors: The Mediating Role of Employee Job Satisfaction, Commitment, and the Moderating Role of Self-Esteem. International Journal of Science Business 5: 44-65.

Yan, Rui, Muhammad Farhan Basheer, Muhammad Irfan, and Tahir Naveed Rana. 2020. Role of Psychological factors in Employee Well-being and Employee Performance: An Empirical Evidence from Pakistan. Revista Argentina de Clínica Psicológica 29: 638.

Yanney, John Parker. 2014. Business strategy and leadership style: Impact on organizational performance in the manufacturing sector of Ghana. American Journal of Industrial Business Management 4: 767. [CrossRef]

Yoshida, Diah Tuhfat, Sen Sendjaya, Giles Hirst, and Brian Cooper. 2014. Does servant leadership foster creativity and innovation? A multi-level mediation study of identification and prototypicality. Journal of Business Research 67: 1395-404. [CrossRef]

Yusuf, Muhammed. 2011. The impact of self-efficacy, achievement motivation, and self-regulated learning strategies on students' academic achievement. Procedia-Social Behavioral Sciences 15: 2623-26. [CrossRef]

Zainal, Veithzal Rivai. 2004. Manajemen Sumber Daya Manusia Perusahaan dari Teori ke Praktik. Jakarta: Raja Grafindo Persada 1: $1-588$.

Zeeshan, Sobia, Siew Imm Ng, Jo Ann Ho, and Amer Hamzah Jantan. 2021. Assessing the impact of servant leadership on employee engagement through the mediating role of self-efficacy in the Pakistani banking sector. Cogent Business Management 8: 1963029. [CrossRef]

Zelenak, Michael S. 2015. Measuring the sources of self-efficacy among secondary school music students. Journal of Research in Music Education 62: 389-404. [CrossRef]

Zhang, Xiaomeng, and Kathryn M. Bartol. 2010. Linking empowering leadership and employee creativity: The influence of psychological empowerment, intrinsic motivation, and creative process engagement. Academy of Management Journal 53: 107-28. [CrossRef]

Zhiqiang, Ma, Hira Salah ud din Khan, Muhammad Salman Chughtai, and Li Mingxing. 2021. Re-Engineering the Human Resource Strategies Amid and Post-Pandemic Crisis: Probing into the Moderated Mediation Model of the High-Performance Work Practices and Employee's Outcomes. Frontiers in Psychology 12: 710266. [CrossRef] [PubMed] 